\title{
KESAN REVOLUSI IR 4.0 TERHADAP PERKEMBANGAN DAN KETEPATAN APLIKASI KIBLAT DALAM TELEFON PINTAR
}

\section{The Effect of Industrial Revolution 4.0 on the Development and Accuracy of the Qiblah Application in Smartphones}

\author{
Nurulhuda Ahmad Zaki* \\ Raihana Abdul Wahab** \\ Mohamaddin Abdul Niri****
}

\begin{abstract}
The IR 4.0 Revolution or known as The Fourth Industrial Revolution or the Digital Era emerged in the late 20th century. The advent of the digital era has had a drastic impact on the smartphone telecommunications industry which is now intelligent artificial with various functions. It not only serves as a telecommunication tool but also as a 'good friend'
\end{abstract}

* Senior Lecturer, Islamic Astronomy Programme, Department of Fiqh and Usul, Academy of Islamic Studies, University of Malaya, Kuala Lumpur. zafran@um.edu.my

** Senior Lecturer, Islamic Astronomy Programme, Department of Fiqh and Usul, Academy of Islamic Studies, University of Malaya, Kuala Lumpur.raihanawahab@um.edu.my

*** Senior Lecturer, Islamic Astronomy Programme, Department of Fiqh and Usul, Academy of Islamic Studies, University of Malaya, Kuala Lumpur. mohammaddin@um.edu.my 
of human beings that provides all the necessary information only through the medium of the Internet network. Realizing the existence of problems of the Muslim public in terms of determining the direction of qiblah, the industry took the opportunity to create qiblah application in smartphones through the Play Store medium. Of course on the basis of profit, the company or private produce various qiblah applications that are improved regularly according to the needs of users. In fact, the development of the aircraft transport industry and the tourism industry further boosted the needs of consumers for the qiblah application as well as stimulate the production of qiblah applications in the Play Store. The objective of this study is to gauge the error that exists in qiblah applications tested at different locations. Ironically, there were qiblah applications that merely disappeared, or were renamed and there are added new ones in the Play Store. As a result of the update in January 2018, it was found that a total of 248 qiblah applications existed in smartphones. However, this number changed to 226 applications on the April 2018 update date. This shows that the number of qiblah applications in the Play Store varies from time to time. The question is whether the accuracy of the qiblah applications available in the Play Store today is influenced by different locations. A total of 20 qiblah applications were randomly selected. The test results showed that the error and qiblah difference varied at each observation location. Hence, the results of this study can be a reference for the Muslim community to choose applications that have minimal error rates in order to determine the direction of the qiblah to perform șalāh.

Keywords: qiblah application, Play Store, Smart Phone, Revolution IR 4.0 


\section{PENDAHULUAN}

Dalam 20 tahun kebelakangan ini, dunia menyaksikan pertumbuhan dan perubahan jangka panjang dalam bidang ICT (Komunikasi dan Teknologi Maklumat) seperti perlaksanaan pembuatan telefon serta internet dalam bidang ICT. Pembuatan telefon dan fungsinya berubah dengan ketara seiring perubahan revolusi dan turut dipengaruhi oleh internet yang memberi impak sangat besar dalam seluruh kehidupan manusia di dunia ini. Pada peringkat awal, gerak kerja dalam kehidupan masyarakat adalah berasaskan tenaga manusia dan haiwan. ${ }^{1}$

Namun, kemunculan revolusi 1.0 yang dikenali sebagai revolusi industri mengubah sistem tradisional ${ }^{2}$ kepada penggunaan mesin seperti kemunculan mesin wap yang merubah sistem ekonomi masyarakat yang lebih berdaya maju dan pantas. Kemunculan revolusi 2.0 memperlihatkan ciptaan telefon rumah berasaskan tenaga motor. ${ }^{3}$ Telefon rumah berwayar tersebut hanya berfungsi sebagai alat telekomunikasi semata-mata. Namun kemunculan fungsi internet dalam ICT ketika revolusi industri 3.0 menyaksikan perubahan yang sangat besar kepada dunia komunikasi. Ketika ini telefon tanpa wayar dilahirkan dan memiliki fungsi yang lebih luas seperti sudah boleh dibawa ke mana-mana dan memiliki fungsi digital pada skrinnya. Kemunculan revolusi 4.0 memaparkan ledakan terhadap pembuatan serta penghasilan telefon pintar. Telefon ini dinamakan telefon pintar kerana menggabungkan

1 M.A. Ghufron, "Revolusi Industri 4.0: Tantangan, Peluang dan Solusi Bagi Dunia Pendidikan," (Kertas kerja, Seminar National dan Diskusi Panel Multidisplin Hasil Penelitian dan Pengabdian Kepada Masyarakat, Jakarta, Indonesia, 2 Ogos 2018), 332.

2 Oussama Meski, Farouk Belkadi, Florent Laroche \& Benoit Furet, "Towards A Knowledge-based Framework for Digital Chain Monitoring within the Industry 4.0 Paradigm," (Proceeding CIRP 84, 2019), 118-123.

3 Aminatuz Zahrah \& Achmad Fawaid, "Halal Food di Era Revolusi Industri 4.0: Prospek dan Tantangan," Jurnal Hayula: Indonesian Journal of Multidisciplinary Islamic Studies 3, no. 2 (2019), 122. 
fungsi kamera, teks, peti suara, pemain media dan pelayar web. ${ }^{4}$ Telefon pintar juga lahir bersama-sama dengan fungsi internet yang merupakan sumber utama terhadap perkembangan pesat teknologi telekomunikasi. Perkembangannya bersifat global di seluruh dunia dan ini telah menjadikan Barat sebagai peneraju utama dalam teknologi telekomunikasi masa kini. ${ }^{5}$

Umumnya, pengaruh internet dalam teknologi pembuatan telefon menjadikan corak aplikasinya berubah kepada multifunction. Kini telefon bukan saja berfungsi sebagai alat telekomunikasi semata-mata malah meluas terhadap sumber produktiviti harian seperti dapatan maklumat global, hiburan, penyelesai masalah, membeli belah, membuat transaksi kewangan serta sumber ekonomi manusia. ${ }^{6}$ Maka tidak hairan jika dinyatakan bahawa telefon merupakan sahabat baik manusia pada masa kini. Menurut rekod, manusia menggunakan telefon pintar sekurangkurangnya 5 jam setiap hari. ${ }^{7}$ Ini menunjukkan pengaruh internet dan telefon pintar sangat kuat terhadap kehidupan manusia masa kini.

$4 \quad$ Nik Mohd Firdaus Nik Zainal Abidin, Farahwahida Mohd Yusof \& Nurshuhadak Hehsan, "Aplikasi Iphone: Antara Teknologi Maklumat dan Komunikasi, Media Sosial dan Sebaran Dakwah," Sains Humanika 2, no. 1 (2014), 41-53.

$5 \quad$ Ir. Budi Handrianto, "Islamisasi Ilmu Pengetahuan di Era Revolusi Industri 4.0 (Makna dan Tantangannya)," The Annual Conference on Islamic Education and Social Science 1, no. 1 (2019), 1-13.

6 Mazumder, T. A., Student, M. S., Light, F., Networking, S., \& Players, V., "Mobile Application and Its Global Impact 1," International Journal of Engineering \& Technology 10, no. 6 (2010), 72-78.

7 Sumaiya Mushroor, ShamminHaque, \& Riyadh A. Amir, "The Impact of Smart Phones and Mobile Devices on Human Health and Life," International Journal of Community Medicine and Public Health 7, no. 1 (2020), 9-15. 
Kemunculan telefon pintar mendorong kepada tertubuhnya Play Store ${ }^{8}$ yang menjadi salah satu jantung kepada akses kehidupan manusia dalam dunia internet masa kini. Play Store merupakan satu platform aplikasi terbesar dalam telefon pintar. Play Store memuatkan sehingga jutaan aplikasi hasil kemaskini pada September 2011. ${ }^{9}$ Jumlah ini bertambah seiring pertambahan aplikasi baru yang memasuki pasaran Play Store tersebut dan meluaskan lagi jaringan perniagaan ${ }^{10}$ dalam dunia telekomunikasi. Pada masa kini, aplikasi dalam Play Store merupakan antara pelayar yang tertinggi dilayari oleh pengguna telefon pintar. Berdasarkan rekod, 100 juta aplikasi di muat turun sejak tahun $2008 .^{11}$

Muslim masa kini turut menggunakan aplikasi dalam telefon pintar untuk membantu mereka dalam aspek ibadah seperti aplikasi kiblat. Gaya hidup mereka yang gemar melancong ke luar negara mendorong mereka menggunakan aplikasi sebagai penunjuk arah kiblat ketika melaksanakan solat. Pelbagai syarikat persendirian, atau swasta berlumba-lumba menghasilkan aplikasi kiblat dalam Play Store. Kini terdapat beratus-ratus aplikasi kiblat yang dihasilkan tanpa batasan dan masih belum teruji sepenuhnyaoleh

$8 \quad$ Play Store adalah suatu peranti yang memuatkan jutaan aplikasi di dalamnya, yang menyediakan perkhidmatan kepada telefon jenis android. Terdapat jutaan aplikasi yang berbeza agama yang boleh dimuat turun oleh ramai pengguna. Lihat Anum Hamee, Hafiza Anisa Ahmed \& Narmeen Zakaria Bawan, "Survey, Analysis and Issues of Islamic Android Apps," Elkawnie: Journal of Islamic Science and Technology 5, no. 1 (2019), 2.

9 Shubham Ruhela, "Google Playstore Application Analysis and Prediction", (Kertas Projek, Bachelor of Technology in Computer Science and Engineering, Jaypee University of Information Technology Waknaghat, India, 2019), 3.

10 Anum Hamee, Hafiza Anisa Ahmed \& Narmeen Zakaria Bawan, "Survey, Analysis and Issues of Islamic Android Apps," 1.

11 Hemraj Saini, "Google Playstore Application Analysis and Prediction," (Latihan Ilmiah, Ijazah Sarjana Komputer Sains dan Engineering, Universiti Teknologi Maklumat JaypeeWaknaghat, India, 2019), 3. 
pakar bidang. ${ }^{12}$ Memandangkan ia melibatkan aspek ibadah umat Islam, maka sewajarnya aplikasi-aplikasi tersebut diuji ketepatannya agar tidak menimbulkan keraguan dalam aspek kesahan ibadah yang dilaksanakan oleh Muslim sejagat.

Rajah 1: Revolusi dan Proses Ciptaan Telefon Pintar dan Aplikasi Kiblat

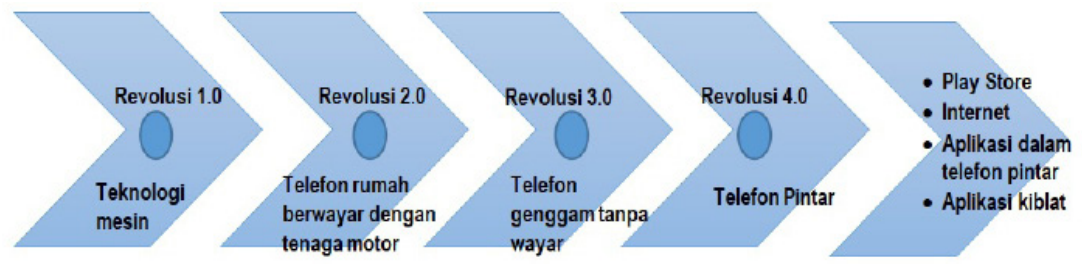

\section{SOROTAN LITERATUR}

Kemunculan revolusi industri 4.0 telah membuka laluan kepada perluasan fungsi internet sekali gus menaiktaraf ciptaan telefon pintar. Telefon pintar mempunyai fungsi yang sangat luas terutama apabila Play Store menjadi salah satu elemen dalam alat telekomunikasi tersebut. Play Store menjadi medium kewujudan jutaan aplikasi termasuk aplikasi keagamaan iaitu aplikasi kiblat. Namun setiap aplikasi yang diwujudkan mempamerkan kemajuan pembuatan dan kemajuan teknologi seiring zaman revolusi industri 4.0 pada masa kini. Kemajuan teknologi yang muncul dalam revolusi industri 4.0 telah mengubah pembuatan keseluruhan aspek industri dalam negara termasuk kecerdasan buatan, robotik, internet, pengkomputeran dan percetakan 3D.

Antara kemajuan pembuatan yang dapat dilihat dengan jelas adalah menerusi aplikasi kiblat yang dicipta dalam Play Store. Kajian oleh Fathurahman ${ }^{13}$ memperlihatkan aplikasi kiblat dihasilkan berdasarkan aplikasi web based yang dirun

12 Fajri Zulia Ramdhani, "Kontribusi Pemuda dalam Digitalisasi Ilmu Falak Pada Aplikasi Islamicastro dan Faza Haul," (Latihan Ilmiah, Ijazah Sarjana, Pascasarjana Universitas Islam Negeri Sunan Ampel, Surabaya, 2020), 5.

13 Fajar Fathurahman, "Innovative Development of Mobile Application for Qibla Direction Guidance Services Training," Ilomata International Journal of Social Science 1, no. 3 (2020), 88-102. 
berdasarkan fungsi android. Dalam kajian Mahmoud dan Norashikin ${ }^{14}$ menunjukkan aplikasi kiblat yang dihasilkan berdasarkan teknologi PIC Microcontroller, dengan fungsi Global Positioning System dan Digital Compass. Malah aplikasi tersebut turut menggunakan fungsi bluetooth dan kedudukan seseorang ditetapkan menggunakan PDA. Menurut kajian Febria Roosita Dwi ${ }^{15}$ pula menunjukkan syarikat telekomunikasi Apple menghasilkan aplikasi kiblat khusus untuk fungsi telefon Apple berasaskan fungsi IOS. Selain itu, kajian oleh Tarek Haissam Mahmoud $^{16}$ menunjukkan pelbagai teknologi digunakan dan dimuatkan dalam aplikasi kiblat yang berfungsi sebagai alat penunjuk kiblat yang tepat. Antara teknologi yang dimuatkan dalam alat tersebut untuk mempertingkatkan lagi fungsi aplikasi tersebut ialah magnetic sensor, audio directional output, laser projection dan GPS. Kajian lepas oleh Delikostidis et al. ${ }^{17}$ pula melakukan kajian terhadap penyelidikan-penyelidikan lepas yang menggunakan persekitaran maya untuk menilai aplikasi telefon pintar.

Dalam satu kajian yang menarik iaitu Ronizam Ismail et al. ${ }^{18}$ beliau telah melakukan kajian literatur terhadap 50 produk berunsurkan aplikasi Islam. Beliau mendapati peranti mudah alih

14 Mahmoud I Abdallah Ibrahim \& Norashikin, "Universal Qibla and Prayer Time Finder," International Journal of Electrical and Computer Engineering (2009), 1818.

15 Febria Roosita Dwi, "IOS Application for Finding Halal Food, Mosque, Qibla Direction and Prayer Time," Jurnal Informatika 13, no. 2 (2015), 63-70.

16 Tarek Haissam Mahmoud, "Qibla Orientation Device," https:// patents.google.com/patent/US8898012B2/en, dicapai pada 10 November 2020.

17 Delikostidis, Ioannis, Thore Fechner, Holger Fritze, Ahmed Mahmoud AbdelMouty \& Christian Kray, "Evaluating Mobile Applications in Virtual Environments: A Survey," International Journal of Mobile Human Computer Interaction 5, no. 4 (2013): $1-19$.

18 Ronizam Ismail, Shahrul Niza Samsudin, Wahid Ab Sulaiman, Norzaimah Zainol, \& Dina Syafini Zaid, "Kajian Tinjauan Literature Terhadap Aplikasi Mudah Alih Berunsurkan Islam Islamic Mobile Apps," (Kertas kerja, 1st International Islamic Heritage Conference, Akademi Pengajian Islam Kontemporari, UiTM Melaka, 2015), 373. 
terawal berinspirasikan Islam diperkenalkan pada tahun 2004 iaitu Ilkone I800. Aplikasi ini menggunakan telefon pintar dan hotline Islam. Bermula daripada aplikasi inilah maka tercetusnya pelbagai aplikasi Islam yang lain termasuk aplikasi kiblat dalam telefon pintar. Berdasarkan rekod, aplikasi berunsurkan Islam merupakan aplikasi tertinggi dimuat turun oleh pengguna telefon pintar. Kecenderungan terhadap kemajuan teknologi dalam revolusi industri 4.0 menggalakkan lagi penghasilan aplikasi sehingga berlaku lambakan aplikasi tersebut dalam Play Store. Hasil penelitian oleh Anum Hamee et al. ${ }^{19}$ mendapati aplikasi berunsurkan Islam dalam Play Store tersebut tidak dikategorikan secara sistematik menyebabkan kekeliruan dan kesukaran pengguna mencari aplikasi yang dikehendaki.

Kajian yang dijalankan oleh Fajri Zulia ${ }^{20}$ menemukan 15 aplikasi yang berkaitan dengan falak seperti waktu solat, kiblat, takwim dan kitab falak. Namun menurut beliau, aplikasi-aplikasi ini dihasilkan oleh pengeluar yang bukan dalam bidang ilmu falak. Ini menimbulkan keraguan terhadap ketepatan aplikasiaplikasi yang dihasilkan. Ini mendorong pelbagai penyelidik dalam lapangan ilmu falak mengkaji aplikasi-aplikasi tersebut dalam pelbagai aspek seperti kajian ketepatan aplikasi dalam telefon pintar. Kajian oleh yang Mustofa Kamal ${ }^{21}$ merupakan kajian yang menguji ketepatan aplikasi google earth dan kompas kiblat menggunakan teknik triangulasi. Hasil ujikaji ini terhadap beberapa surau dan masjid sekitar Desa Blendung, Indonesia, terdapat ralat dalam aplikasi tersebut sekitar $17^{\circ}-26^{\circ}$. Selisih atau ralat $1^{\circ}$ memberi kesan kepada terpesongnya arah kiblat sehingga $180 \mathrm{~km}$. Ini bermakna $26^{\circ}$ ini memberi kesan terpesong arah kiblat pada jarak 4,680 km dari Kaabah.

\footnotetext{
19 Anum Hamee, Hafiza Anisa Ahmed \& Narmeen Zakaria Bawan, "Survey, Analysis and Issues of Islamic Android Apps," 3.

20 Fajri Zulia Ramdhani, "Kontribusi Pemuda dalam Digitalisasi Ilmu Falak Pada Aplikasi Islamicastro dan Faza Haul," 5.

21 Mustofa Kamal, "Teknik Penentuan Arah Kiblat Menggunakan Aplikasi Google Earth dan Kompas Kiblat RHI," Jurnal Madaniyah 2, no. 9 (2015), 176.
} 
Kajian lain yang hampir sama, Zahrotun Niswah ${ }^{22}$ menguji ketepatan kompas arah kiblat dalam aplikasi android iaitu digital falak versi 2 menerusi kajian lapangan dan cerapan. Aplikasi kiblat tersebut dihasilkan oleh seorang ahli falak Indonesia bernama Ahmad Tholhah Ma'ruf. Hasil kajian beliau mendapati, aplikasi tersebut sangat tepat dengan nilai selisih yang lebih kecil berbanding teodolit yang dikenali sebagai instrumen falak yang memiliki nilai ralat terkecil berbanding instrumen lain. Kajiankajian lain yang menguji ketepatan aplikasi kiblat dalam Play Store berasaskan android ialah Nilna Minakhah, ${ }^{23}$ Nur Sidqon ${ }^{24}$ dan Muhammad Nu'man. ${ }^{25}$ Kajian oleh H. Ahmad Izzuddin ${ }^{26}$ dan Anisah Budiwati ${ }^{27}$ melaksanakan kajian menguji ketepatan kaedah penentuan arah kiblat termasuk global positioning system (GPS) dan google earth yang menjadi asas dalam ciptaan beberapa aplikasi kiblat.

22 Zahrotun Niswah, "Uji Akurasi Kompas Arah Kiblat dalam Aplikasi Android Digital Falak Versi 2.0.8 Karya Ahmad Tholhah Ma'ruf," (Latihan Ilmiah Sarjana, Fakultas Syariah dan Hukum, Universitas Islam Negeri Walisongo, Semarang, 2018), 5.

23 Nilna Minakhah, "Studi Akurasi Aplikasi Android Ismicastro Versi 1.8.12 dalam Penentuan Arah Kiblat," (Latihan Ilmiah Ijazah Sarjana, Jurusan Ilmu Falak Fakultas Syariah dan Hukum Universitas Islam Negeri Walisongo Semarang, Indonesia, 2019), xiii.

24 Nur Sidqon, "Uji Akurasi Mizwandroid Karya Hendro Setyanto," (Latihan Ilmiah Ijazah Sarjana, Fakultas Syari'ah dan Hukum Universitas Islam Negeri Walisongo, Semarang, Indonesia, 2019), ix.

25 Muhammad Nu'man Alkarim, "Perancangan Aplikasi Perhitungan Rashdul Kiblat Harian Dengan Java 2 Micro Edition (J2ME) Pada Mobile Phone," (Latihan Ilmiah Ijazah Sarjana, Jurusan Ilmu Falak Fakultas Syariah Universiti Islam Negeri Walisongo, Semarang, Indonesia, 2015), xiii.

26 H. Ahmad Izzuddin, "Metode Penentuan Arah Kiblat dan Akurasinya," (Kertas kerja, Conference Proceeding Annual International Conference on Islamic Studies AICIS IAIN Sunan Ampel Surabaya, Indonesia, 2012), 759.

27 Anisah Budiwati, "Tongkat Istiwa' Global Positioning System (GPS) dan Google Earth Untuk Penentuan Menentukan Titik Koordinat Bumi dan Aplikasinya dalam Penentuan Arah Kiblat," Jurnal AlAhkam 26, no. 1 (2016), 65. 
Selain itu, para pengkaji dalam lapangan ilmu falak turut mengambil inisiatif menghasilkan aplikasi-aplikasi kiblat dalam Play Store. Aplikasi yang dihasilkan diuji terlebih dahulu agar tepat dan diyakini untuk kegunaan penentuan arah kiblat. Kajian Rikky Wisnu Nugraha dan Endro Wibowo ${ }^{28}$ memperkenalkan aplikasi baru bernama Kupluk dalam sistem Android untuk tujuan menentukan waktu solat dan arah kiblat serta aplikasi ini telah diuji ketepatannya oleh penyelidik. Dalam kajian yang hampir sama oleh Muhammad Amiral, ${ }^{29}$ turut menguji Kupluk namun berasaskan sistem android yang telah dikemaskini kepada android 1.6. Mizwandroid pula adalah contoh aplikasi kiblat juga berasaskan andorid yang telah teruji ketepatannya. Ia mengaplikasikan sensor magnetik, kompas juga kamera pada telefon pintar yang boleh digunakan secara universal di serata dunia. ${ }^{30}$

28 Rikky Wisnu Nugraha \& Endro Wibowo, "Aplikasi Pengingat Shalat dan Arah Kiblat Menggunakan GPS Berbasis Android," Jurnal LPKIA 4, no. 2 (2014), 19.

29 Muhammad Amiral, "Aplikasi Pengingat Shalat dan Arah Kiblat Menggunakan Global Positioning System (GPS) Berbasis Android 1.6," (Projek Akhir Peringkat Ijazah, Program Studi Teknik Informatika, Institut Teknologi Indonesia, Indonesia, 2010), i.

30 Nur Sidqon, "Uji Akurasi Mizwandroid Karya Hendro Setyanto," ix. 
Selain itu banyak kajian aplikasi dalam Play Store dijalankan namun dalam pelbagai bidang termasuklah pendidikan, ${ }^{31}$ bahasa, ${ }^{32}$

31 Esteban Vazquez-Cano, "Mobile Distance Learning with Smartphones and Apps in Higher Education," Educational Sciences: Theory \& Practice, 14, no. 4 (2014), 1505-1520; Yousef Mehdipour \& Hamideh Zerehkafi, "Mobile Learning for Education: Benefits and Challenges," International Journal of Computational Engineering Research 3, no. 6 (2013), 93.

32 Robert Godwin-Jones, "Emerging Technologies Mobile Apps For Language Learning," Language Learning \& Technology 15, no. 2 (2011), 2-11; Kara Clayton, Thurston High School \& Amanda Murphy, "Smartphone Apps in Education: Students Create Videos to Teach Smartphone Use as Tool for Learning," Journal of Media Literacy Education 8, no. 2 (2016), 99-109; Jonathan P. Rossing, Willie M. Miller, Amanda K. Cecil \& Suzan E. Stamper, "iLearning: The Future of Higher Education? Student Perceptions on Learning with Mobile Tablets," Journal of the Scholarship of Teaching and Learning (2011), 2; Chui Yin Wong, Chee Weng Khong \& Kimberly $\mathrm{Chu}$, "Interface Design Practice and Education Towards Mobile Apps Development," Procedia - Social and Behavioral Sciences 51 (2012), 698-702; Radoslava Kraleva \& Velin Kralev, “An Evaluation of The Mobile Apps for Children with Specia Education Needs Based on The Utility Function Metrics," International Journal on Advance Science Engineering Information Technology 8, no. 6 (2018), 2269. 
budaya, ${ }^{33}$ kesihatan, ${ }^{34}$ dan pelancongan..$^{35}$ Pada tahun 2018, penyelidik telah menjalankan satu kajian menyerupai kajian ini, namun kajian tersebut menfokuskan kepada perbezaan data kiblat oleh dua model telefon yang berbeza iaitu Asus Zenfone dan Huwei P9 Lite. Walaupun 20 jenis aplikasi yang diuji adalah sama, namun hasil azimut kiblat yang ditunjukkan adalah berbeza dalam kedua-dua jenis model telefon pintar sekali gus membuktikan telefon pintar yang berbeza akan menghasilkan nilai bacaan azimut kiblat yang berbeza. ${ }^{36}$ Oleh yang demikian, berdasarkan soroton kajian-kajian lepas dapat disimpulkan masih kurangnya kajian yang menyerupai kajian penyelidik iaitu kesan revolusi industri 4.0 terhadap perkembangan dan ketepatan aplikasi kiblat dalam telefon pintar masa kini. Oleh itu kajian ini dijalankan untuk mengisi kelompongan tersebut.

33 Frans Mayra, "Playful Mobile Communication: Services Supporting the Culture of Play," Interactions: Studies in Communication \& Culture 3, no. 1 (2012), 55-70.

34 Kevin Anderson, Oksana Burford \& Lynne Emmerton, "Mobile Health Apps to Facilitate Self-Care: A Qualitative Study of User Experiences," PLOS ONE (2016), 1; Karandeep Singh, Kaitlin Drouin, Lisa P. Newmark, JaeHo Lee, Arild Faxvaag, Ronen Rozenblum, Erika A. Pabo, Adam Landman, Elissa Klinger, and David W. Bates, "Many Mobile Health Apps Target High-Need, High-Cost Populations, But Gaps Remain," Health Affairs 35 (2016), 12; Wei Peng, Shaheen Kanthawala, Shupei Yuan \& Syed Ali Hussain, "A Qualitative Study of User Perceptions of Mobile Health Apps," BMC Public Health 16 (2016), 1158.

35 Janet E. Dickinson, Viachaslau Filimonau, Tom Cherrett, Nigel Davies, Julia F. Hibbert, Sarah Norgate \& Chris Speed, "Lifeshare Using Mobile Apps in Tourism: The Role of Trust, Sense of Community and Existing Lift-share Practices," Transportation Research Part D 61 (2018), 397-405; Heather Kennedy-Eden \& Ulrike Gretzel, "A Taxonomy of Mobile Applications in Tourism," (Research Online, University of Wollongong, 2012), 47.

36 Nurulhuda \& Muhammad Asyraff Anuar, "Analisis Perbandingan Aplikasi Penentuan Arah Kiblat dalam Telefon Pintar Asus Zenfone 2 dan Huawei P9 Lite," Voice of Academia 13, no. 2 (2018), 35-47. 


\section{APLIKASI KIBLAT DAN KESAN REVOLUSI IR 4.0 TERHADAP PERKEMBANGAN APLIKASI KIBLAT DALAM PLAY STORE}

\section{Aplikasi Kiblat dalam Telefon Pintar}

Perkembangan telefon dalam dunia telekomunikasi telah memberi kesan serta pengaruh kewujudan aplikasi dalam Play Store. Aplikasi merupakan sejenis perisian yang dibina bertujuan memberi kemudahan kepada pengguna dalam menjalankan tugas seharian. ${ }^{37}$ Aplikasi mula wujud apabila berlaku perkembangan dalam bidang telekomunikasi dan telefon pintar. Teknologi telefon dilihat mula berkembang sekitar tahun 2005 apabila syarikat telefon bimbit selular mengambil alih pasaran talian tetap..$^{38}$ Apabila teknologi telefon makin berkembang, penggunaan telefon tidak hanya terhad kepada aspek telekomunikasi semata-mata malah meliputi pelbagai aspek lain dalam memberi kemudahan kepada manusia. Berdasarkan rekod, jumlah pengguna telefon pintar meningkat sehingga $81 \%$ pada tahun 2012 berbanding tahun 2011 hanya 19\% dalam kalangan pembeli telefon pintar. Sekali gus peningkatan telefon pintar ini memberi kesan terhadap pertumbuhan aplikasi dalam telefon pintar yang memiliki medium muat turun tersendiri iaitu App Store dan Play Store. ${ }^{39}$

Terdapat jutaan aplikasi dalam telefon pintar. Sebahagian daripadanya merupakan aplikasi kiblat yang menggunakan kompas, gps dan magnetometer dalam telefon pintar untuk berfungsi menunjukkan arah kiblat yang diingini. Hasil penelitian dan pencarian aplikasi kiblat dalam Play Store didapati jumlahnya

37 Nik Mohd Firdaus Nik Zainal Abidin, Farahwahida Mohd Yusof \& Nurshuhadak Hehsan, "Aplikasi Iphone: Antara Teknologi Maklumat dan Komunikasi, Media Sosial dan Sebaran Dakwah," 41-53.

38 Nik Mohd Firdaus Nik Zainal Abidin, Farahwahida Mohd Yusof \& Nurshuhadak Hehsan, "Aplikasi Iphone: Antara Teknologi Maklumat dan Komunikasi, Media Sosial dan Sebaran Dakwah,” 41-53.

39 Karima Moumane, Ali Idri \& Alain Abran, "Usability Evaluation of Mobile Applications Using ISO 9241 and ISO 25062 Standard," Springer Plus 5 (2016), 548. 
berubah-ubah tanpa sekatan. Pada Januari 2018, jumlah aplikasi kiblat ialah 248, namun berubah kepada 226 pada April 2018. ${ }^{40}$ Jadual 1 di bawah merupakan paparan 42 jenis aplikasi kiblat daripada keseluruhan yang wujud dalam Play Store. Aplikasi ini dipilih berdasarkan muat turun pengguna yang melebihi 500,000 aplikasi pada tarikh kemaskini bermula Januari 2017 hingga April 2018. Jumlah muat turun yang tinggi dalam jadual ini menunjukkan kadar pengguna yang tinggi yang memerlukan aplikasi kiblat untuk keperluan Muslim.

$40 \quad$ Nurulhuda \& Muhammad Asyraff Anuar, "Analisis Perbandingan Aplikasi Penentuan Arah Kiblat dalam Telefon Pintar Asus Zenfone 2 dan Huawei P9 Lite," 35-47. 
Kesan Revolusi IR 4.0 Terhadap Perkembangan dan Ketepatan Aplikasi Kiblat dalam Telefon Pintar

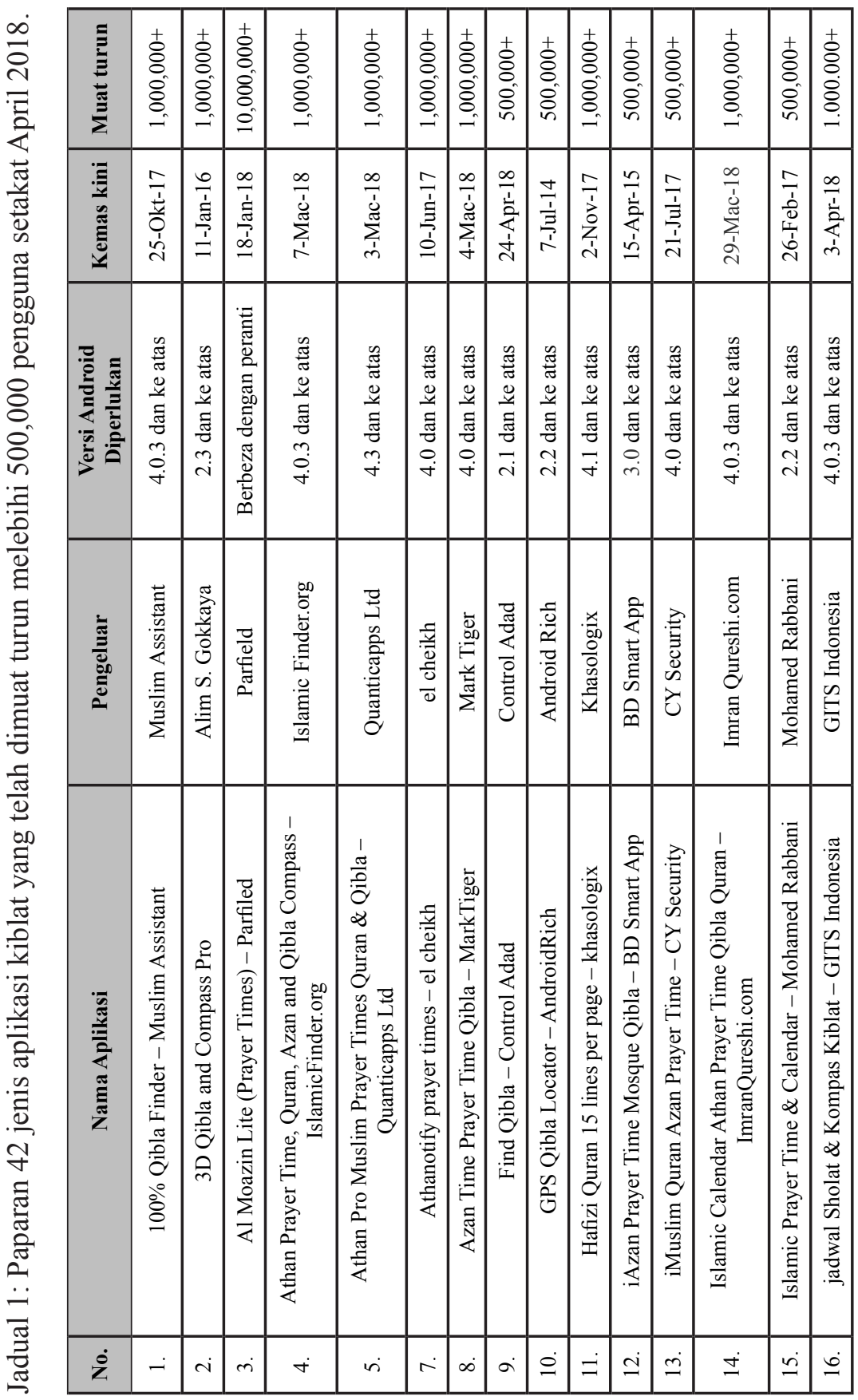




\begin{tabular}{|c|c|c|c|c|c|c|c|c|c|c|c|c|c|}
\hline N. & $\infty$ & $\stackrel{N}{.}$ & Na & $\stackrel{N}{\sim}$ & $\stackrel{\sim}{\perp}$ & $\underset{\omega}{\sim}$ & $\stackrel{N}{N}$ & $\stackrel{N}{\sim}$ & $\stackrel{N}{\circ}$ & $\vec{\bullet}$ & $\vec{\infty}$ &. & ? \\
\hline 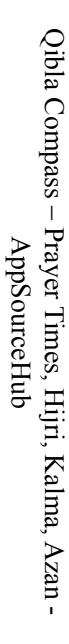 & 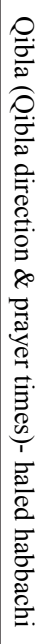 & 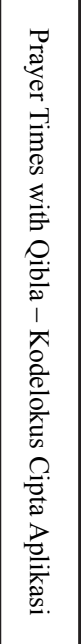 & 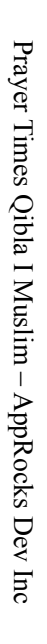 & 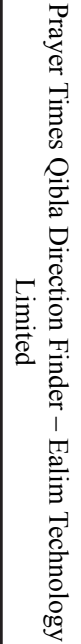 & 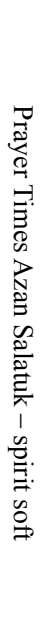 & 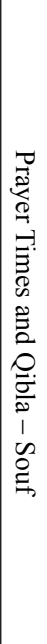 & 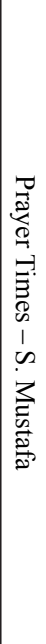 & 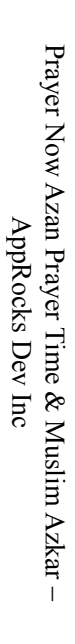 & 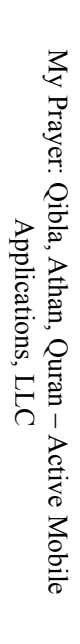 & 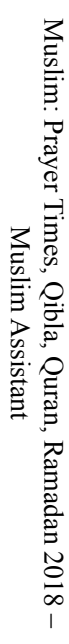 & 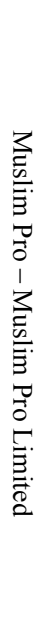 & 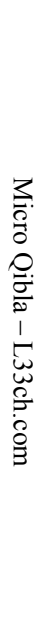 & 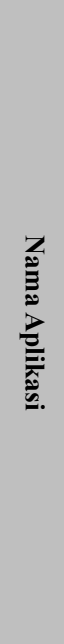 \\
\hline 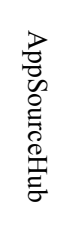 & 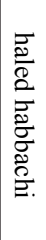 & 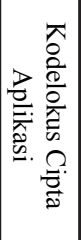 & 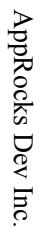 & 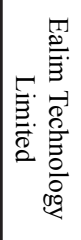 & 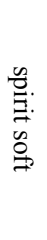 & 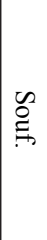 & 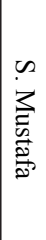 & 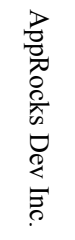 & 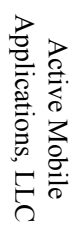 & 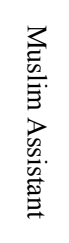 & 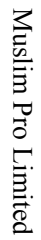 & 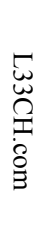 & 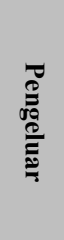 \\
\hline 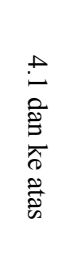 & 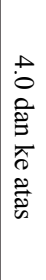 & 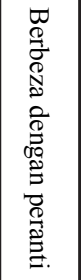 & 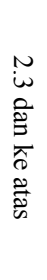 & 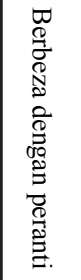 & 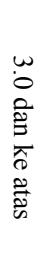 & 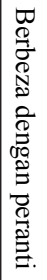 & 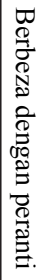 & 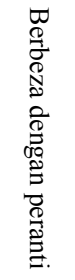 & 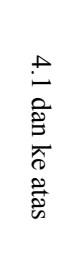 & 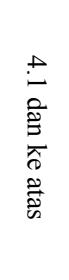 & 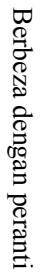 & 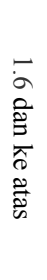 & 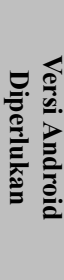 \\
\hline$\frac{N}{+}$ & 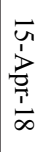 & 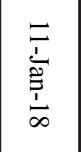 & $\begin{array}{l}\vec{y} \\
\dot{0} \\
\frac{0}{2} \\
\vec{t} \\
\dot{u}\end{array}$ & 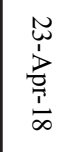 & $\begin{array}{l}\frac{N}{3} \\
\frac{3}{3} \\
\frac{9}{1} \\
\frac{1}{V}\end{array}$ & 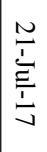 & 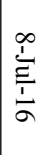 & $\frac{N}{N}$ & \begin{tabular}{l}
$w$ \\
0 \\
0 \\
0 \\
00 \\
0 \\
0 \\
$\vdots$ \\
\multirow{1}{*}{}
\end{tabular} & \begin{tabular}{l}
$\infty$ \\
\multirow{2}{*}{} \\
$\stackrel{1}{1}$ \\
$\stackrel{1}{1}$ \\
$\infty$
\end{tabular} & 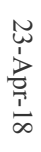 & $\begin{array}{l}\bar{N} \\
\frac{1}{3} \\
\frac{0}{1} \\
\frac{1}{u}\end{array}$ & 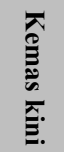 \\
\hline $\begin{array}{l}5 \\
8 \\
8 \\
\circ \\
8 \\
\circ\end{array}$ & $\begin{array}{l}5 \\
8 \\
8 \\
\circ \\
\circ \\
8 \\
0\end{array}$ & $\begin{array}{l}\text { \& } \\
8 \\
\circ \\
8 \\
\circ\end{array}$ & $\begin{array}{l}\dot{8} \\
8 \\
8 \\
8 \\
8 \\
0\end{array}$ & $\begin{array}{l}u \\
\ddot{8} \\
8 \\
\stackrel{8}{8} \\
\stackrel{8}{+}\end{array}$ & $\begin{array}{l}5 \\
\stackrel{8}{8} \\
8 \\
8 \\
8 \\
0\end{array}$ & 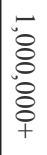 & 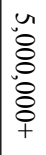 & $\begin{array}{l}\text { ஜ8 } \\
8 \\
\circ \\
8 \\
8\end{array}$ & 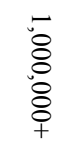 & 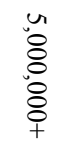 & $\begin{array}{l}0 \\
\stackrel{0}{8} \\
8 \\
\circ\end{array}$ & $\begin{array}{l}5 \\
\stackrel{8}{8} \\
8 \\
8 \\
8 \\
0\end{array}$ & 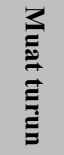 \\
\hline
\end{tabular}


Kesan Revolusi IR 4.0 Terhadap Perkembangan dan Ketepatan Aplikasi Kiblat dalam Telefon Pintar

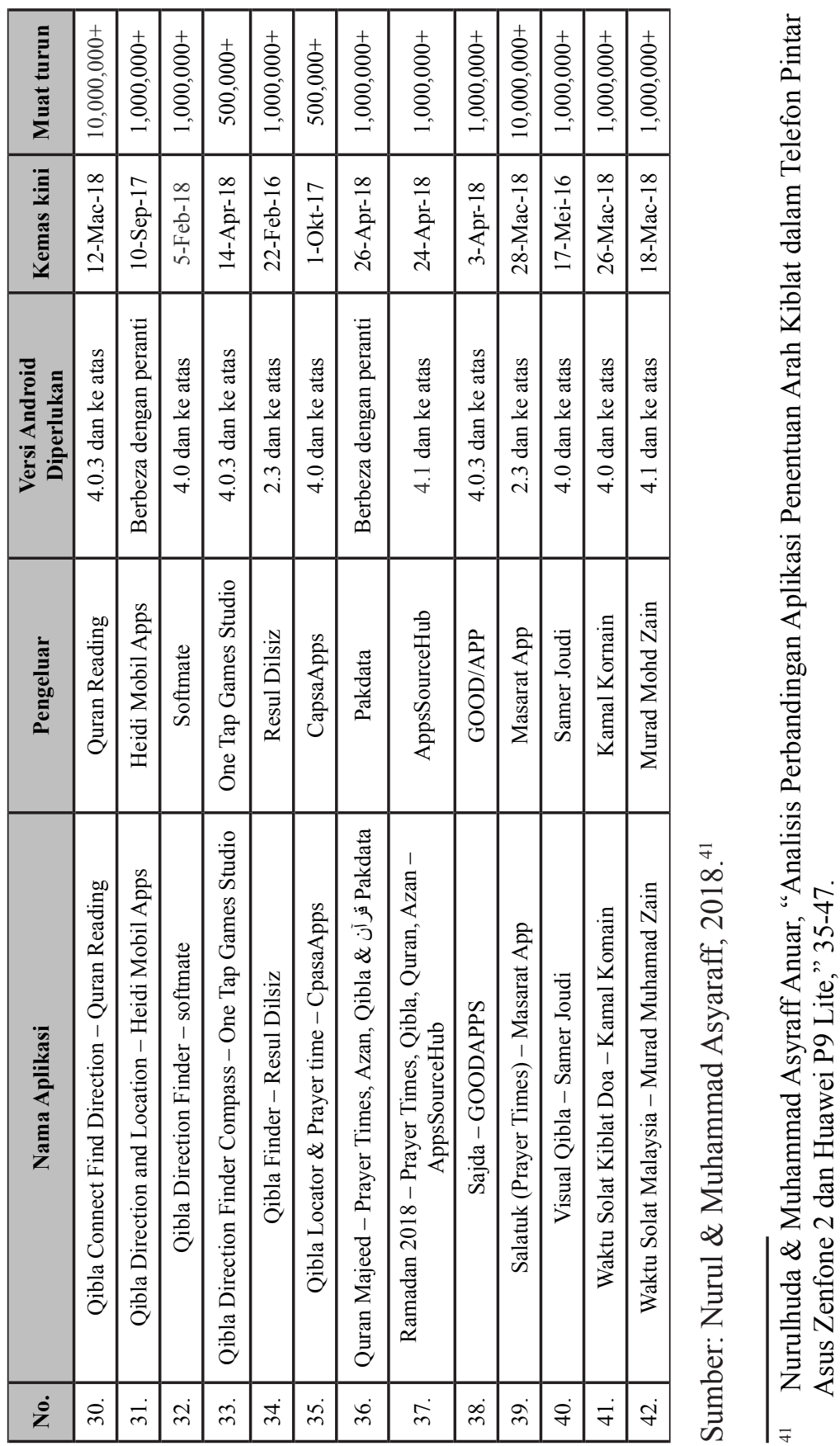




\section{Kesan Revolusi Industri Terhadap Aplikasi Kiblat dalam Play Store}

Aplikasi kiblat merupakan aplikasi yang digunakan sebagai petunjuk arah kiblat kepada Muslim ketika laksanakan solat. Pada masa kini, keperluan pengguna terhadap aplikasi kiblat dilihat berada pada tadap yang tinggi berdasarkan jumlah muat turun yang ditunjukkan. Selain itu, penghasilan dan pengeluaran aplikasi kiblat dalam jumlah lambakan yang tinggi juga menunjukkan kadar keperluan pengguna yang semakin meningkat. Kemunculan revolusi industri 4.0 telah menggalakkan lagi kerancakan muat turun aplikasi kiblat oleh pengguna. Ini dapat dilihat menerusi kadar muat turun aplikasi berunsurkan Islam termasuk aplikasi falak meningkat dengan kadar yang tinggi dalam jadual 1 di atas. Anum Hameed et al juga menyatakan aplikasi berunsurkan Islam merupakan aplikasi tertinggi digunakan oleh pengguna dalam Play Store. ${ }^{42}$

Ini terjadi kesan revolusi industri terhadap ciptaan telefon pintar. Telefon pintar dilihat berkembang dari aspek fungsi, pembuatan, dan kelajuan internet. Beberapa kemajuan yang jelas terlihat ialah jumlah pengguna meningkat setelah telefon pintar berkembang maju sekitar tahun 2014 hinggakan 85\% pengguna menyatakan alat tersebut merupakan sebahagian daripada keperluan hidup mereka. ${ }^{43}$ Setelah revolusi industri terjadi, kelajuan internet dinaiktaraf daripada 3G, 4G dan kini kepada 5G. ${ }^{44}$ Rangkaian internet yang meningkat ini walaupun pada kadar capaian 4G telah meningkatkan kestabilan dan kelajuan internet. Kesannya, direkodkan pengguna internet mencapai jumlah yang sangat tinggi iaitu sebanyak 2 bilion pada masa kini. Peningkatan pengguna telefon pintar mencapai hampir kepada $100 \%$ dengan

\footnotetext{
42 Anum Hamee, Hafiza Anisa Ahmed \& Narmeen Zakaria Bawan, "Survey, Analysis and Issues of Islamic Android Apps," 9.

43 Karima Moumane, Ali Idri \& Alain Abran, "Usability Evaluation of Mobile Applications Using ISO 9241 and ISO 25062 Standard," 548.

44 Anum Hamee, Hafiza Anisa Ahmed \& Narmeen Zakaria Bawan, "Survey, Analysis and Issues of Islamic Android Apps," 1.
} 
peningkatan $1 \%$ setiap tahun di negara maju, manakala $20 \%$ setahun di negara membangun. ${ }^{45}$

Selain itu, revolusi industri turut memberi kesan terhadap lambakan jumlah aplikasi yang tinggi dalam Play Store tanpa had dan batasan. Direkodkan terdapat kira-kira 28 million aplikasi wujud setelah berlaku perubahan terhadap kelajuan capaian internet. ${ }^{46}$ Jumlah aplikasi ini akan terus meningkat saban hari. Ini kerana ia berkait rapat dengan aspek perniagaan ${ }^{47}$ yang menyebabkan syarikat-syarikat pengeluar dan orang persendirian berusaha mengeluarkan pelbagai aplikasi yang canggih demi keuntungan dan keperluan pengguna. Kita dapat melihat trend peningkatan jumlah aplikasi berdasarkan jumlah muat turun aplikasi oleh pengguna secara keseluruhan sebanyak 10.9 bilion pada tahun 2010. Ia meningkat kepada 29 billion pada tahun 2011 dan 76.9 billion pada tahun 2014 di seluruh dunia, dengan jumlah kos keseluruhan sebanyak USD35 bilion. ${ }^{48}$

Kesan seterusnya ialah dari segi pembangunan aplikasi dalam Play Store. Terdapat pelbagai jenis bahasa pemprograman yang digunakan dan ia berubah seiring perubahan teknologi dalam telefon pintar. Antara bahasa pemprograman yang digunakan ialah Java Emulator yang terdapat dalam aplikasi Rashdul Kiblat ${ }^{49}$ dan juga Phyton. Phyton ini banyak digunakan dalam pembuatan

45 Nik Mohd Firdaus Nik Zainal Abidin, Farahwahida Mohd Yusof \& Nurshuhadak Hehsan, "Aplikasi Iphone: Antara Teknologi Maklumat dan Komunikasi, Media Sosial dan Sebaran Dakwah," 41-53.

46 Anum Hamee, Hafiza Anisa Ahmed \& Narmeen Zakaria Bawan, "Survey, Analysis and Issues of Islamic Android Apps," 1.

47 Harleen K. Flora, Xiaofeng Wang \& Swati V. Chande, "An Investigation on the Characteristics of Mobile Applications: A Survey Study," I.J. Information Technology and Computer Science, 11 (2014), 21-27.

48 Henry Muccini, Antonio Di Francesco \& Patrizio Esposito, "Software Testing of Mobile Applications: Challenges and Future Research Directions," (Proceeding, Paper Presented on International Workshop on Automation of Software Test (AST), Zurich, Switzerland on 2-3 June 2012).

49 Muhammad Nu'man Alkarim, "Perancangan Aplikasi Perhitungan Rashdul Kiblat Harian Dengan Java 2 Micro Edition (J2ME) Pada Mobile Phone," 36. 
Irobot, Google dan Intel. ${ }^{50}$ Selain itu, aplikasi dalam telefon pintar turut berubah berdasarkan kepelbagaian teknologi seperti pembinaan berasaskan web based application, ${ }^{51}$ teknologi GPS ${ }^{52}$ magnetic sensor, sistem audio, dan laser projection. ${ }^{53}$

Seterusnya, pengeluaran aplikasi kiblat masa kini tidak hanya dikeluarkan oleh Muslim, sebaliknya turut didominasi oleh syarikat-syarikat telekomunikasi barat seperti Apple dan Android. Negara barat merupakan negara yang maju dalam pelbagai aspek telekomunikasi. Namun Ir Budi Handrianto menegaskan, kesan revolusi 4.0 telah mendorong kepada kemajuan sains barat yang bersifat sekular iaitu bebas dari unsur agama. ${ }^{54}$ Situasi ini sudah tentu membimbangkan kerana pengeluaran dan penghasilan aplikasi oleh mereka berkait rapat dengan ibadah umat Islam. Selain itu, kesan yang ketara adalah pembuatan dan pengeluaran aplikasi kiblat dikembangkan oleh pengeluar yang bukan dari bidang falak. Ini juga menyebabkan aplikasi yang dihasilkan tidak tepat dan tidak teruji ketepatannya. ${ }^{55}$ Namun kita tidak boleh menafikan kekuatan dan kebijaksanaan teknologi barat. Tanpa teknologi tersebut, kita tidak mampu menghasilkan aplikasi sendiri. Bahkan pengetahuan tentang agama dan falak masih belum mampu membantu seseorang menghasilkan aplikasi dengan tepat. ${ }^{56}$ Maka integrasi antara teknologi barat dan kepakaran daripada ahli falak

50 Hemraj Saini, "Google Playstore Application Analysis and Prediction," (Latihan Ilmiah, Ijazah Sarjana Komputer Sains dan Engineering, Universiti Teknologi Maklumat JaypeeWaknaghat, India, 2019), 18.

51 Fajar Fathurahman, "Innovative Development of Mobile Application for Qibla Direction Guidance Services Training," 88-102.

52 Mahmoud I Abdallah Ibrahim \& Norashikin, "Universal Qibla and Prayer Time Finder," 1816; Muhammad Amiral, “Aplikasi Pengingat Shalat dan Arah Kiblat Menggunakan Global Positioning System (GPS) Berbasis Android 1.6," 39; Rikky Wisnu Nugraha \& Endro Wibowo, "Aplikasi Pengingat Shalat dan Arah Kiblat Menggunakan GPS Berbasis Android," 21.

53 Tarek Haissam Mahmoud, "Qibla Orientation Device."

54 Ir. Budi Handrianto, "Islamisasi Ilmu Pengetahuan di Era Revolusi Industri 4.0 (Makna dan Tantangannya)," 1-13.

55 Fajri Zulia Ramdhani, "Kontribusi Pemuda dalam Digitalisasi Ilmu Falak Pada Aplikasi Islamicastro dan Faza Haul," 5.

56 Ibid. 
sangat diperlukan dalam penghasilan aplikasi falak yang tepat dan diuji keberkesanannya.

\section{METODOLOGI KAJIAN}

\section{Lokasi Cerapan}

Dalam kajian ini, penyelidik dan pembantu penyelidik telah melaksanakan kajian cerapan di beberapa lokasi yang berlainan profil. Tujuan utama adalah untuk menilai kesan lokasi cerapan terhadap ketepatan aplikasi kiblat. Pemilihan ini dengan mengambilkira kesan tarikan magnet jarum kompas terhadap jarak kedudukan besi yang boleh menyebabkan tarikan magnetik berlaku. Profil yang dipilih adalah berdasarkan kawasan bebas magnetik serta di bawah pengaruh magnetik. Empat kawasan bebas magnetik dipilih dan kesemuanya ditentukan berdasarkan kepada jarak yang berlainan. Masjid Lanchang Pahang merupakan lokasi cerapan dengan radius jarak melebihi 10 meter dari kawasan tarikan magnet. Lokasi Masjid Lanchang dipilih kerana kedudukannya sangat jauh daripada pengaruh besi dan bangunan. Persekitaran kampung dan dikelilingi pokok boleh diklasifikasikan sebagai tempat bebas tarikan magnet.

Koordinat Masjid Lanchang ini ialah $3^{\circ} 29^{\prime} 29.64^{\prime \prime} \mathrm{U}, 102^{\circ}$ 12'37.3” T. Manakala dua lokasi pantai dipilih iaitu Pantai Morib, Selangor (koordinat $2^{\circ} 45^{\prime} 1.86^{\prime \prime} \mathrm{U}, 101^{\circ} 26^{\prime} 32.2^{\prime \prime}$ T) dan Pantai Port Dickson, Negeri Sembilan (koordinat $2^{\circ} 24^{\prime}$ 53.0" U, $101^{\circ}$ 51 ' 30.2" T) dengan mengambilkira pengaruh besi dari lokasi cerapan sejauh 5 meter. Profil yang hampir sama dipilih iaitu blok D, Akademi Pengajian Islam Universiti Malaya (APIUM) (koordinat $3^{\circ} 7{ }^{\prime} 59^{\prime \prime} \mathrm{U}, 101^{\circ} 39^{\prime} 28^{\prime \prime} \mathrm{T}$ ) dengan radius tarikan magnet berjarak 3 meter. Seterusnya dua lagi kawasan dipilih sebagai lokasi cerapan berdasarkan kawasan di bawah pengaruh medan magnet yang tinggi. Pertama di dalam bangunan Blok $\mathrm{C}$ APIUM (koordinat 3 7' 58.92" U, 101 ${ }^{\circ} 39^{\prime} 26.1^{\prime \prime} \mathrm{T}$ ). Kedua ialah Bukit Fraser (koordinat $3^{\circ} 42$ ' 49.8" U, 101 ${ }^{\circ} 44^{\prime} 4.92$ " T) yang mengambilkira kawasan bersebelahan bangunan hotel. Maklumat lanjut tentang lokasi cerapan boleh dirujuk dalam jadual 2 di bawah. 
Jurnal Fiqh, Vol. 17 No. 2 (2020) 267-308

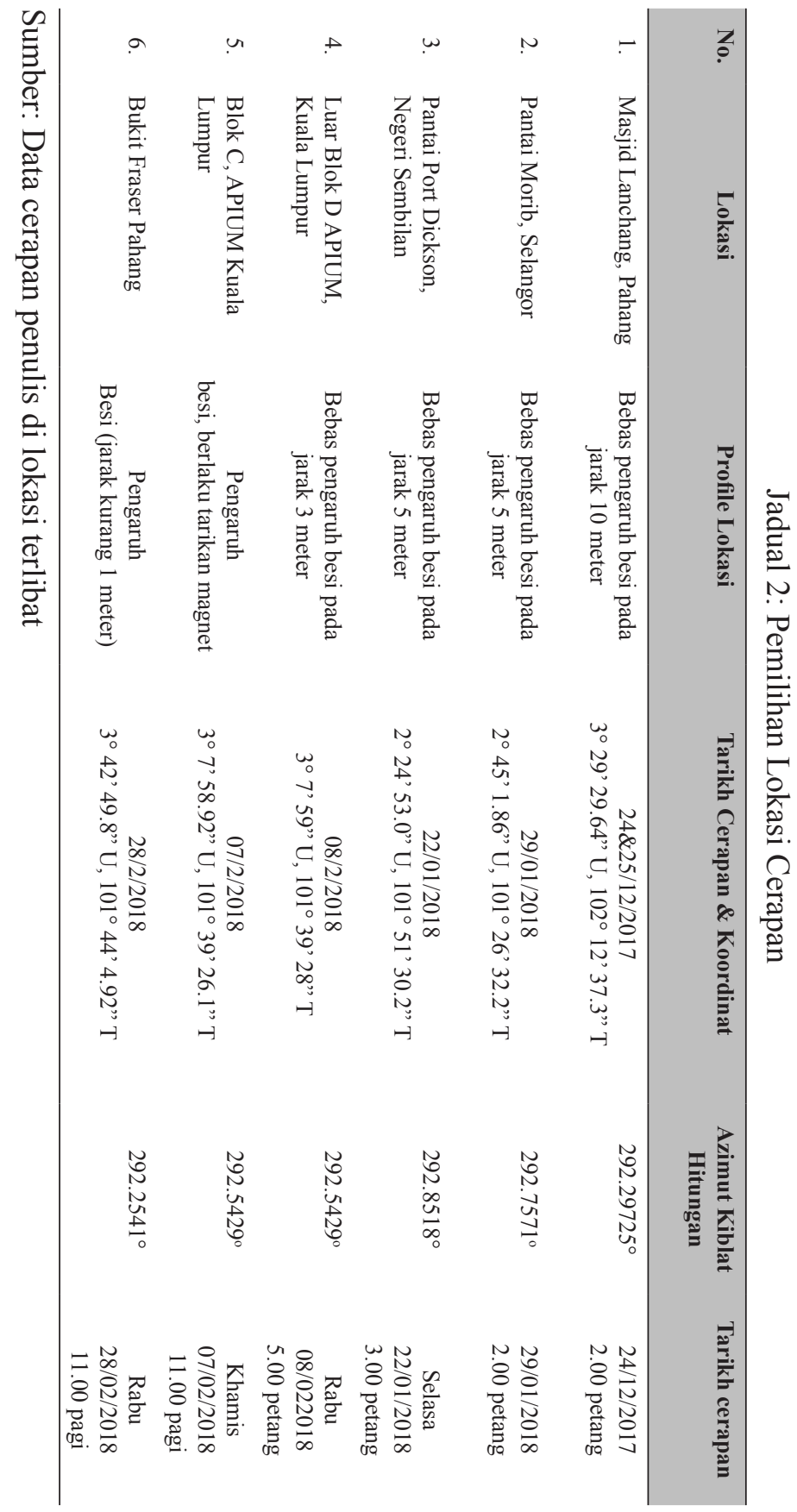




\section{Model Telefon Pintar Huawei P9 Lite}

Telefon pintar jenis Huawei P9 Lite dipilih kerana memiliki fungsi magnetometer, sensor kompas dan GPS. Ciri-ciri ini penting agar proses cerapan menggunakan aplikasi kiblat dapat dijalankan. Telefon pintar jenis Huawei ini merupakan telefon pintar jenis Android. Android merupakan sebuah sistem operasi telefon pintar yang menyediakan platform terbuka dalam pengembangan aplikasi tersendiri. ${ }^{57}$ Jadual 3 di bawah menunjukkan ciri-ciri telefon pintar tersebut.

Jadual 3: Ciri-ciri Telefon Pintar Huawei P9 Lite

\begin{tabular}{|c|c|c|}
\hline Ciri-ciri & & Huawei P9 Lite \\
\hline \multirow[t]{2}{*}{ Features } & Sensor & $\begin{array}{l}\text { Fingerprint, accelerometer, proximity, } \\
\text { compass }\end{array}$ \\
\hline & Browser & HTML5 \\
\hline \multirow[t]{2}{*}{ Comms } & $W L A N$ & Wi-Fi $802.11 \mathrm{~b} / \mathrm{g} / \mathrm{n}$, Wi-Fi Direct, hotspot \\
\hline & GPS & Yes, with A-GPS, GLONASS \\
\hline \multirow[t]{4}{*}{ Platform } & $O S$ & $\begin{array}{l}\text { Android } 6.0 \text { (Marshmallow), upgradable } \\
\text { to } 7.0 \text { (Nougat) }\end{array}$ \\
\hline & Chipset & HiSilicon Kirin 650 \\
\hline & $C P U$ & $\begin{array}{l}\text { Octa-core }(4 x 2.0 \mathrm{GHz} \text { Cortex-A53 \& } 4 x 1.7 \\
\text { GHz Cortex-A53) }\end{array}$ \\
\hline & $G P U$ & Mali-T830MP2 \\
\hline
\end{tabular}

Sumber: Nurul \& Muhammad Asyaraff, 2018. ${ }^{58}$

57 Agustian Noor, "Aplikasi Kisah 25 Nabi dan Rasul Berbasis Android," Jurnal Sains dan Informatika 2, no. 2 (2016), 76.

58 Nurulhuda \& Muhammad Asyraff Anuar, "Analisis Perbandingan Aplikasi Penentuan Arah Kiblat dalam Telefon Pintar Asus Zenfone 2 dan Huawei P9 Lite," 35-47. 


\section{Kaedah Hitungan Azimut Kiblat}

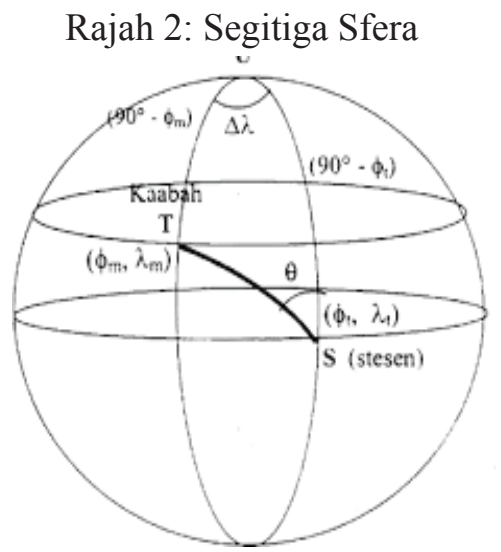

Sumber: Jabatan Mufti Pulau Pinang. ${ }^{59}$

Azimut kiblat dihitung berdasarkan formula trigonometri sfera. Formula ini diperolehi berasaskan kepada segitiga yang dibentuk daripada bulatan besar dalam sistem sfera samawi. Berdasarkan rajah 2 di atas, UTS merupakan segitiga tersebut. U merujuk kepada kutub Utara yang menjadi asas rujukan hitungan. T merujuk kepada lokasi kaabah. Nilai koordinat kaabah ialah latitud mekah ( $\phi m$ ) $21^{\circ} 25^{\prime}$ 15.6" $U$; nilai longitud mekah ( $\lambda$ m ) $39^{\circ} 49^{\prime} 29.1$ 'T. Manakala S merujuk kepada stesen rujukan ataupun lokasi hitungan kiblat. Nilai koordinat ini dapat diperolehi dalam www.map.gov.my. Nilai yang dicari berdasarkan segitiga sfera, UTS ialah nilai sudut dari Utara $(\theta)$. Sudut ini dapat dicari berdasarkan formula trigonometri sfera. Terdapat banyak formula trigonometri sfera yang wujud dan boleh digunakan untuk tujuan hitungan azimut kiblat. Namun formula standard yang digunakan di Malaysia adalah seperti berikut:

59 Laman web rasmi Jabatan Mufti Pulau Pinang, http://mufti.penang. gov.my/index.php/2014-11-12-02-4839/penerbitan/191-risalah-fita-yin-al-qiblah/file, diakses pada 27 Oktober 2020. 
$\operatorname{Tan} \theta=\sin \Delta \lambda /(k o s \phi t \tan \phi m-\sin \phi t$

$\operatorname{kos} \Delta \lambda)$

$\Delta \lambda=\lambda$ mekah $-\lambda$ lokasi hitungan azimut kiblat

Azimut kiblat $=360^{\circ}-\theta$

(3)

di mana,

$\theta=$ sudut arah kiblat dari utara

$\phi t=$ nilai latitud lokasi hitungan

$\phi m=$ nilai latitud mekah; $21^{\circ} 25^{\prime} 15.6^{\prime \prime} \mathrm{U}$

$\lambda t=$ nilai longitud lokasi hitungan

$\lambda m=$ nilai longitud mekah; 39॰49'29.1'”T

\section{Kaedah Dapatan Data}

Dalam kajian ini, penyelidik telah memilih 20 jenis aplikasi kiblat seperti dalam jadual 4 di bawah. Aplikasi ini dipilih secara rawak, namun dua daripadanya merupakan aplikasi kiblat yang diiktiraf di Malaysia iaitu MyJakim dan Easy Qibla, selebihnya tidak. Namun pemilihan 20 aplikasi tersebut berdasarkan rekod pernah dimuat turun oleh pengguna hasil kemaskini tahun 2018. Namun jadual di bawah memaparkan rekod muat turun hasil kemaskini Oktober 2020. 
Jadual 4: Senarai Aplikasi Kiblat Terpilih

\begin{tabular}{cll}
\hline No. & Nama Aplikasi Pilihan & Jumlah muat turun \\
\hline 1. & Qibla with Azan and Prayer & 50 juta \\
2. & Times & \\
3. & Mibla Compass Sundial Lite & tiada \\
4. & Waktu Solat Malaysia & 1 juta \\
5. & Raudhah & 5 juta \\
6. & Visual Qibla & 100000 \\
7. & GPS Qibla Locator & 50 juta \\
8. & Qibla +5 & 50 juta \\
9. & Athan Plus & tiada \\
10. & iQibla & 50 juta \\
11. & Qibla AR & tiada \\
12. & Qibla Compass & 100 juta \\
13. & Compass Kaabah & 50 juta \\
14. & Qibla Compass - Find & 50 juta \\
& Direction & 1 juta \\
15. & Qibla Locator & \\
16. & Easy Qibla & 50 juta \\
17. & 100\% Qibla Finder & 50,000 \\
18. & Qibla Direction (blue & 5000 \\
19. & Qinterface) & 50 juta \\
20. & interface) & \\
\hline
\end{tabular}


Rajah 3: Langkah-langkah Pengumpulan data Cerapan

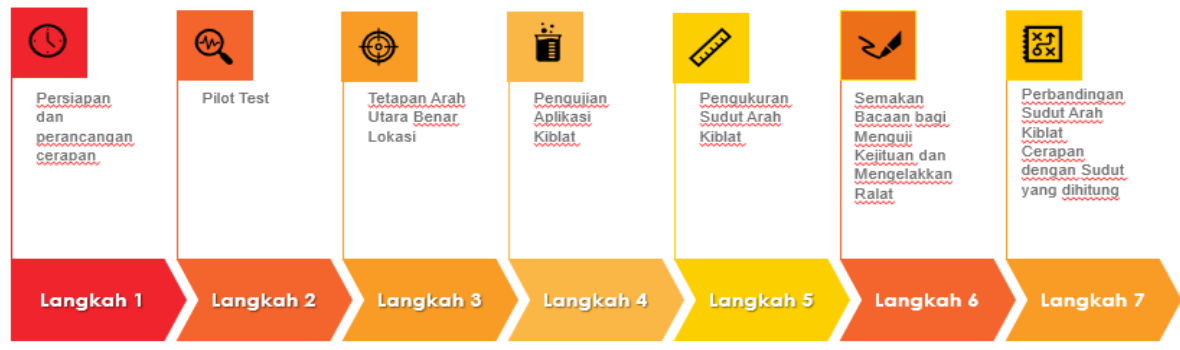

Berdasarkan Rajah 3 di atas, terdapat tujuh langkah bagi proses pengumpulan data cerapan telah dilaksanakan. Langkah pertama merupakan Persiapan dan perancangan cerapan. Terdapat beberapa perancangan yang dilakukan sebelum memulakan aktiviti cerapan. Pertama, pemilihan lokasi cerapan. Penyelidik dan rakan penyelidik menyenaraikan beberapa lokasi cerapan yang berbeza profail. Setiap daripada lokasi cerapan di tempat tersebut ditentukan berdasarkan jarak dari pengaruh besi dan tarikan magnet. Kedua pemilihan telefon pintar. Terdapat beberapa telefon pintar diuji dan didapati telefon jenis Android Huwei P9 Lite sesuai digunakan kerana mempunyai fungsi GPS, magnetometer dan kompas digital.

Langkah kedua, sebelum cerapan sebenar dilakukan di lokasi terpilih, penyelidik dan rakan-rakan melaksanakan pilot test cerapan di lokasi Akademi Pengajian Islam Universiti Malaya terlebih dahulu. Segala prosedur di catat dan kelemahan dalam proses cerapan ini dibincangkan dan dibaiki untuk proses cerapan sebenar akan datang. Antara kelemahan yang perlu di atasi adalah kertas kosong yang digunakan untuk melakarkan arah kiblat hendaklah mengadap arah utara magnet dengan tepat. Ini bagi memastikan sudut arah kiblat yang ditunjukkan oleh aplikasi kiblat dapat dikira dengan baik.

Langkah ketiga, di lokasi cerapan, arah utara ditentukan terlebih dahulu menggunakan sebuah kompas magnetik. Satu kertas kosong diletakkan di atas lokasi cerapan (tanah). Namun keadaan mendatarnya diuji terlebih dahulu menggunakan penimbang air agar telefon pintar dapat diletakkan dalam keadaan $180^{\circ}$ atas permukaan tanah. 
Langkah keempat adalah sehelai kertas kosong diletakkan mengarah ke arah utara. Kemudian telefon pintar diletakkan selari dengan arah utara yang telah ditanda. Kemudian, aplikasi kiblat yang telah di muat turun dibuka dan diuji satu persatu. Arah kiblat yang ditunjukkan oleh aplikasi arah kiblat kemudiannya ditanda dengan berhati-hati di atas kertas kosong yang sama menggunakan pembaris.

Seterusnya langkah kelima adalah sudut yang terbentuk antara utara magnetik dengan arah kiblat yang telah ditanda itu diukur menggunakan pembaris protector digital. Proses ini dilakukan beberapa kali untuk mendapatkan bacaan yang lebih tepat untuk setiap satu aplikasi. Kesemua sudut azimut kiblat yang diperolehi hasil cerapan ini kemudiannya dibandingkan dengan azimut kiblat yang dihitung menggunakan formula trigonometri sfera. Hasil perbandingan ini merupakan nilai selisih ralat yang dicari dan data tersebut dicatatkan dalam jadual 5 di bawah.

\section{DAPATAN KAJIAN DAN PERBINCANGAN}

Manusia telah memanfaatkan revolusi industri dalam pembuatan telefon. Hasilnya wujud teknologi GPS, kompas dan magnetometer dalam telefon pintar pada masa kini. Berdasarkan fungsi-fungsi ini maka aplikasi kiblat dicipta dan digunakan untuk memandu arah kiblat umat Islam di Mekah. Walaupun begitu, pelbagai aspek perlu dikaji memandangkan ia melibatkan aspek ibadah umat Islam. Ketepatan arah kiblat menjamin kesahan ibadah solat umat Islam. Dalam aspek ini, dua elemen digunakan iaitu telefon pintar dan aplikasi kiblat. Oleh demikian, menjadi tugas para penyelidik menguji kedua-dua elemen tersebut dari aspek ketepatan dalam menunjukkan arah kiblat umat Islam. Dalam kajian ini, penyelidik menguji hanya 20 jenis aplikasi kiblat yang terdapat dalam telefon pintar jenis Huawei P9 Lite. Bacaan sudut azimut kiblat yang ditunjukkan oleh 20 jenis aplikasi ini diambil di beberapa lokasi terpilih. Kemudian, bacaan yang ditunjukkan dibandingkan dan dibezakan dengan bacaan sebenar yang diperolehi menerusi hitungan formula trigonometri sfera. Selisihan atau ralat hasil perbezaan data tersebut seterusnya diringkaskan dalam jadual 5 di bawah. 
Kesan Revolusi IR 4.0 Terhadap Perkembangan dan Ketepatan Aplikasi Kiblat dalam Telefon Pintar

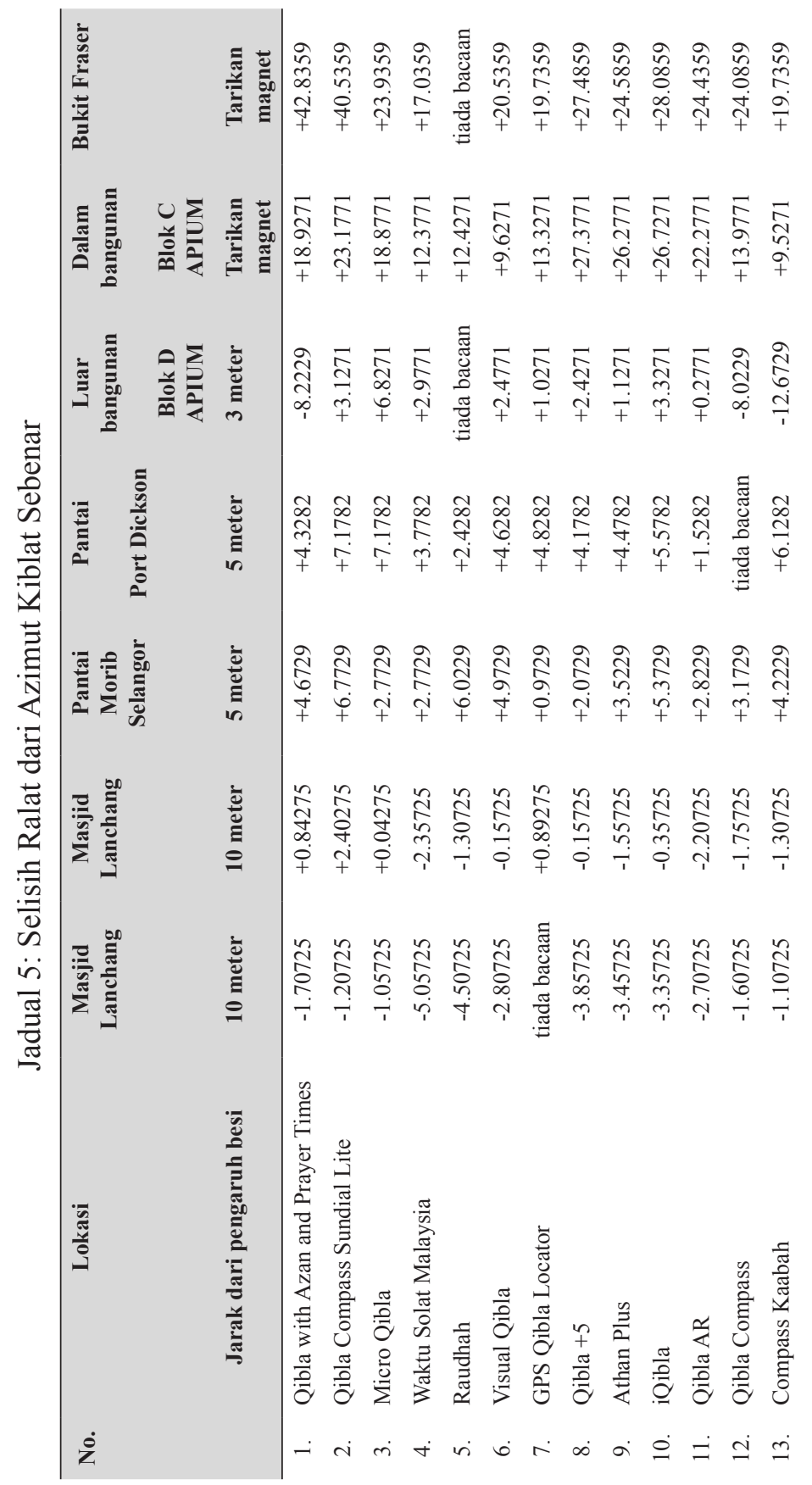


Jurnal Fiqh, Vol. 17 No. 2 (2020) 267-308

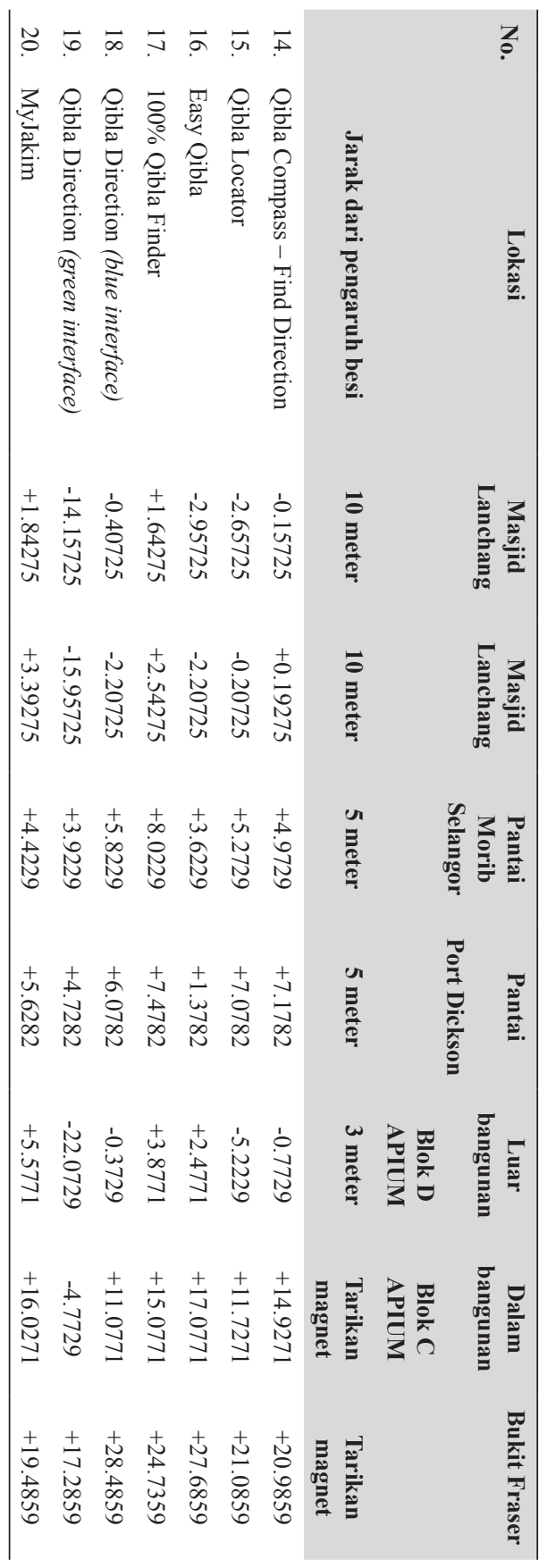


Graf 1: Selisih/Ralat Azimut Kiblat di Semua Lokasi Cerapan
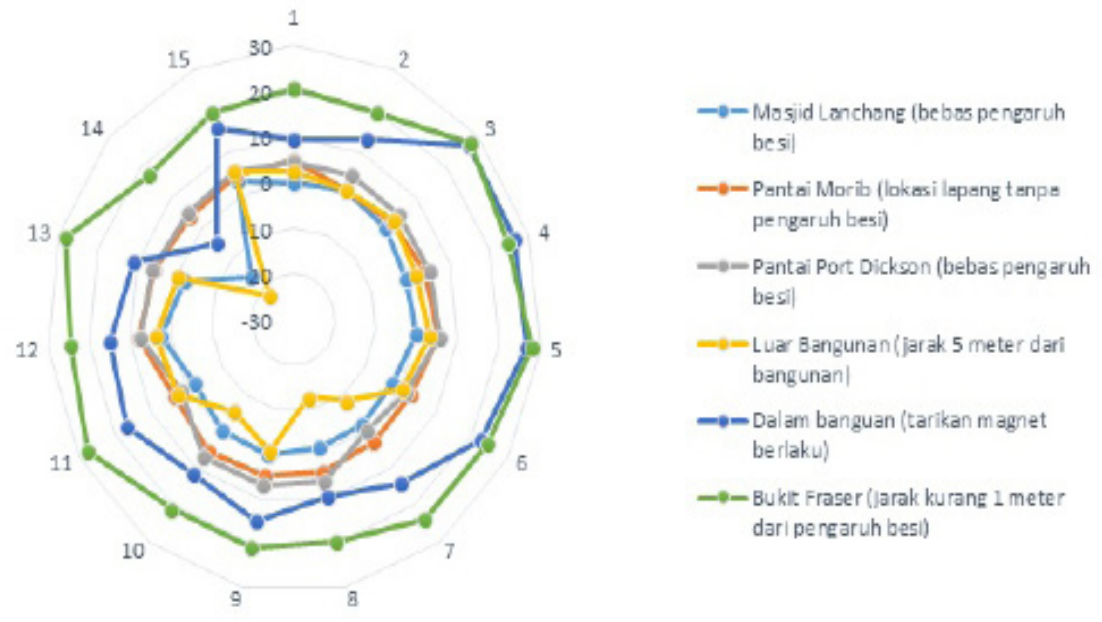

Data selisih/ralat bacaan azimut kiblat yang ditunjukkan dalam Jadual 5 dan diringkaskan dalam Graf 1 di atas. Daripada Graf 1, selisih data bagi garisan berwarna hijau muda dan biru muda sangat ketara bacaannya. Garisan hijau muda merupakan data bacaan bagi lokasi Bukit Fraser manakala garisan biru tua menunjukkan bacaan bagi lokasi dalam bangunan blok C APIUM. Persamaan kedua-dua lokasi ini ialah kedua-duanya merupakan kawasan tarikan magnet yang memberi kesan kepada data yang ditunjukkan oleh 20 aplikasi kiblat yang diuji. Nilai ralat tertingi mencapai $42^{\circ}$ iaitu dari aplikasi Qibla with Azan and Prayer Times yang diuji di lokasi Bukit Fraser. Namun nilai yang ditunjukkan berbeza di lokasi dalam bangunan blok C APIUM dengan nilai $18^{\circ}$. Daripada graf serta paparan nilai selisih yang ditunjukkan, dapat disimpulkan apa jua aplikasi kiblat yang menggunakan kompas tidak boleh digunakan di kawasan tarikan magnet untuk paparan arah kiblat. Ini kerana ralat yang ditunjukkan sangat tinggi 
melebihi had yang dibenarkan iaitu $10^{\circ}$ untuk aplikasi kiblat atau $3^{\circ}$ untuk had selisih arah kiblat yang dibenarkan di Malaysia. ${ }^{60}$

Untuk lokasi-lokasi lain yang bebas pengaruh magnet, keseluruhan bacaan selisih azimut kiblat yang ditunjukkan oleh aplikasi kiblat diterima kerana kurang daripada $10^{\circ}$ kecuali aplikasi Qibla Direction (green interface). Aplikasi ini menunjukkan ralat yang tinggi bagi lokasi Masjid Lanchang Pahang $\left(-14^{\circ}\right)$ dan $\left(-15^{\circ}\right)$ masing-masing bagi tarikh 24 dan 25 Julai serta $-22^{\circ}$ bagi lokasi blok D APIUM. Satu lagi aspek yang perlu diperhatikan ialah, ralat bacaan bagi kesemua aplikasi kecuali Qibla Direction (green interface) berada dalam julat yang hampir sama apabila diuji di kesemua lokasi yang berbeza jarak dari pengaruh tarikan magnet; 10 meter, 5 meter dan 3 meter. Contohnya Easy Qibla memaparkan ralat bacaan purata sekitar $2^{\circ}$ untuk keseluruhan lokasi bebas tarikan magnet, manakala MyJakim, $3^{\circ}$, Visual Qibla, $3^{\circ}$, GPS Qibla Locator, $2^{\circ}$, dan Qibla AR, $1^{\circ}$. Lain-lain aplikasi menunjukkan selisih bacaan yang tidak stabil. Contohnya Qibla with Azan and Prayer Times menunjukkan perbezaan antara $0.84275^{\circ}$ dan $-8.2229^{\circ}$ serta Compass Kaabah antara $-1.10725^{\circ}$ dan $-12.6729^{\circ}$.

Beberapa aspek dinilai berdasarkan beberapa kategori yang berbeza dan ini ditunjukkan dalam graf 2 hingga 3 di bawah. Graf 2 memaparkan data bacaan untuk aplikasi yang diuji di lokasi yang sama (kawasan bebas tarikan magnet) tetapi pada tarikh yang berbeza. Graf 3 pula menunjukkan perbezaan data di dua kawasan pantai yang berjarak 5 meter dari pengaruh besi iaitu Pantai Morib, Selangor dan Pantai Port Dickson, Negeri Sembilan. Manakala graf 4 pula menunjukkan perbezaan data antara dalam bangunan yang memiliki tarikan magnet yang tinggi dengan luar bangunan yang kurang tarikan magnet. Graf 2, 3 dan 4 ini ditunjukkan seperti berikut.

60 Berita Harian, "Tak sah solat guna aplikasi kiblat tersasar jauh daripada Kaabah," https://www.bharian.com.my/taxonomy/ term/1303/2017/07/288125/tak-sah-solat-guna, dicapai pada 29 Mei 2017. 
Graf 2: Perbandingan nilai selisih azimut kiblat di Masjid Lanchang pada 24 dan 25 Julai 2018

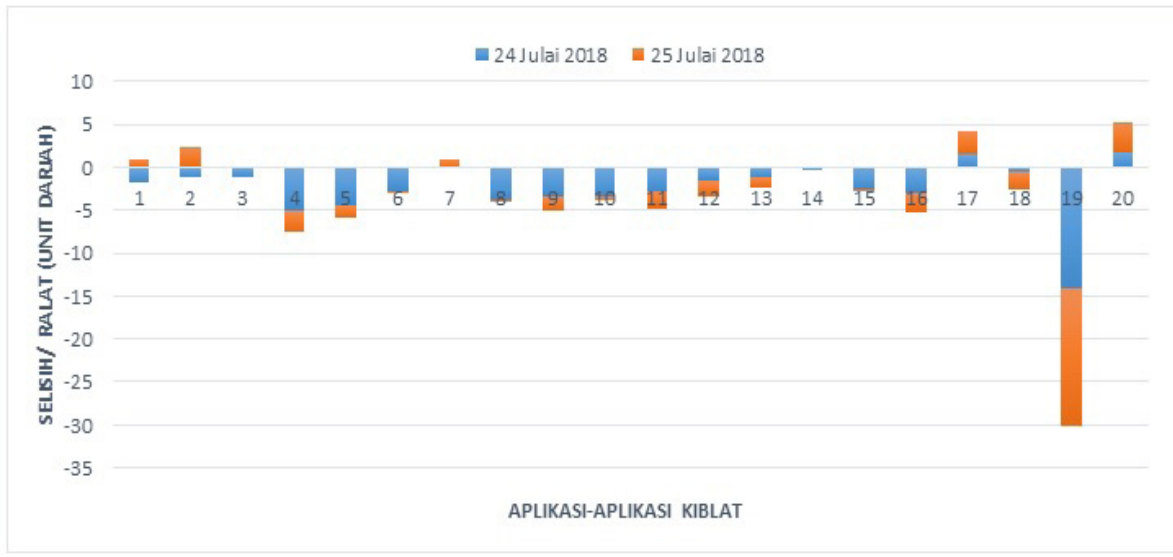

Graf 2 di atas merupakan graf palang bacaan selisih azimut kiblat di lokasi Masjid Lanchang Pahang pada dua tarikh yang berbeza. Secara umumnya, jika aplikasi yang sama diuji di lokasi yang sama walaupun berbeza waktu, sudah tentu bacaan yang ditunjukkan juga akan sama. Namun graf 2 di atas menunjukkan bukti yang sebaliknya. Fokus graf ini adalah untuk menilai perbezaan data azimut kiblat yang ditunjukkan oleh 20 aplikasi yang diuji pada lokasi yang sama tetapi pada tarikh yang berbeza.

Graf palang biru menunjukkan data yang diambil pada 24 Julai manakala graf palang oren menunjukkan data pada 25 Julai. Perbezaan data yang ditunjukkan antara dua tarikh tersebut bagi setiap aplikasi adalah dalam nilai kurang daripada $4^{\circ}$. Perbezaan data paling tinggi ditunjukkan oleh aplikasi Raudhah iaitu $-4.50725^{\circ}$ pada 24 Julai dan $-1.30725^{\circ}$ pada 25 Julai. Kadar perbezaan ini paling tinggi berbanding aplikasi lain. Namun Qibla AR, Qibla Compass, Compass Kaabah, dan Qibla Compass Find Direction merupakan aplikasi-aplikasi yang menunjukkan data bacaan selisih ralat paling hampir antara dua tarikh tersebut. Daripada graf tersebut juga, aplikasi Micro Qibla menunjukkan bacaan selisih paling sedikit dengan kadar ketepatan paling tinggi iaitu dengan bacaan $+0.04275^{\circ}$ yang diambil pada 25 Julai. Manakala aplikasi Qibla Direction (green interface) menunjukkan ralat yang tertinggi iaitu $-15.95725^{\circ}$ yang diambil pada 25 Julai. 
Bagi aplikasi yang diiktiraf iaitu Easy Qibla dan MyJakim, kadar selisih bacaan azimut kurang daripada $4^{\circ}$.

Namun secara keseluruhan dapat disimpulkan bahawa walaupun data selisih ini diambil pada lokasi cerapan yang sama, namun hasil data yang ditunjukkan antara dua tarikh 24 dan 25 Julai 2018 adalah berbeza antara satu sama lain. Selain itu, walaupun lokasi pilihan cerapan data adalah lokasi paling bebas pengaruh magnetik di Masjid Lanchang, Pahang namun bacaan azimut kiblat yang ditunjukkan oleh setiap aplikasi masih menunjukkan ralat berbanding bacaan sebenar. Dan yang paling ketara ialah perbezaan bacaan melebihi $\pm 5^{\circ}$ ialah Qibla Direction (green interface), dan Waktu Solat Malaysia yang diambil pada 24 Julai 2018.

Graf 3: Perbezaan data antara lokasi Pantai Morib, Selangor dan Pantai Port Dickson, Negeri Sembilan.

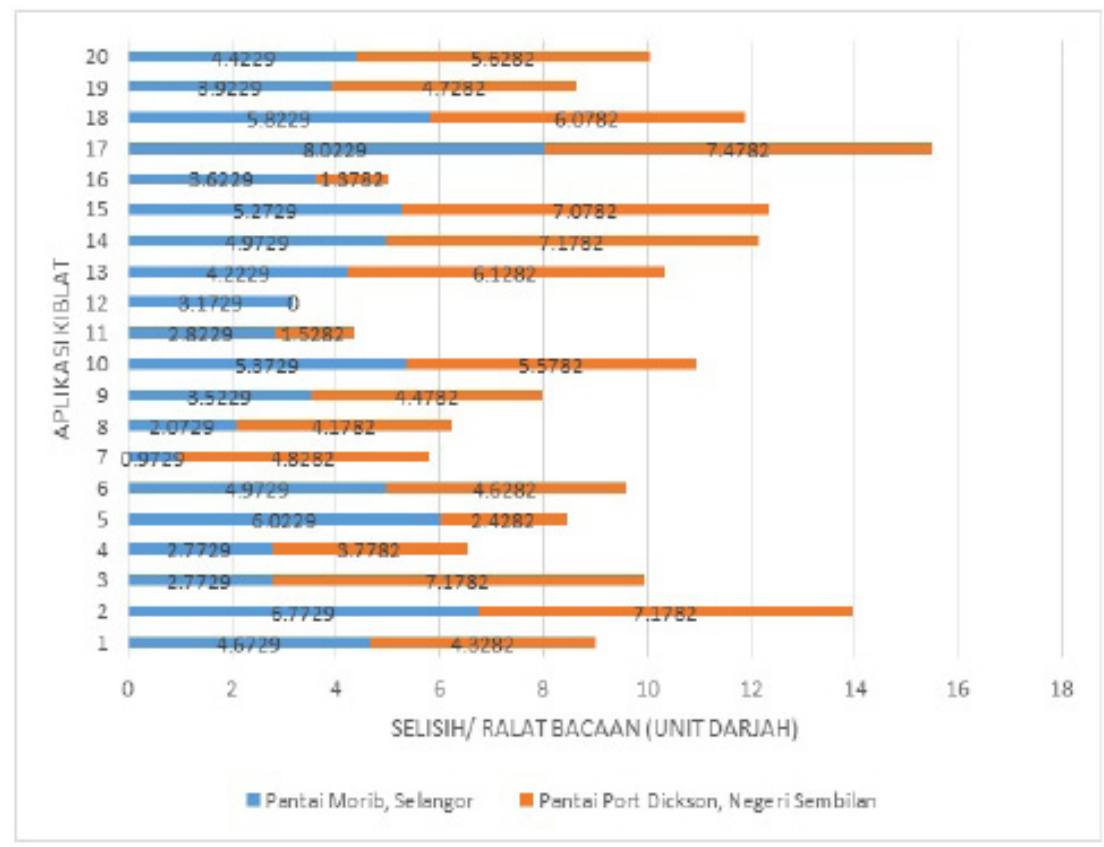

Secara asasnya, kadar ralat antara dua lokasi di atas hendaklah sama. Ini kerana lokasi cerapan mengambilkira kawasan pantai yang berjarak 5 meter daripada pengaruh tarikan magnet (jauh 
dari pengaruh besi atau bangunan). Walaupun kedua-dua pantai ini terletak di lokasi yang berbeza, namun Pantai Morib Selangor dan Pantai Port Dickson Negeri Sembilan merupakan pantai yang luas, serta berada jauh daripada pengaruh besi. Namun selisih bacaan yang ditunjukkan dalam Graf 2 dan 3 memaparkan keputusan data yang berbeza. Garisan graf berwarna biru menunjukkan bacaan yang diambil di lokasi Pantai Morib Selangor manakala warna oren di lokasi Pantai Port Dickson Negeri Sembilan. Daripada keseluruhan aplikasi yang diuji, kadar perbezaan yang ditunjukkan antara kedua-dua lokasi tidak terlalu tinggi, hanya sekitar $2^{\circ}$. Hanya dua aplikasi menunjukkan kadar perbezaan yang ketara iaitu Micro Qibla, $4^{\circ}$ dan Raudhah, $5^{\circ}$. Secara keseluruhannya, selisih data bacaan maksimum adalah $+8.0229^{\circ}$ iaitu aplikasi $100 \%$ Qibla Finder yang diuji di Pantai Morib, Selangor. Manakala selisih data bacaan minimum adalah $+0.9729^{\circ}$ iaitu aplikasi GPS Qibla Locator.

Graf 4: Perbandingan nilai selisih azimut kiblat antara lokasi dalam dan luar bangunan

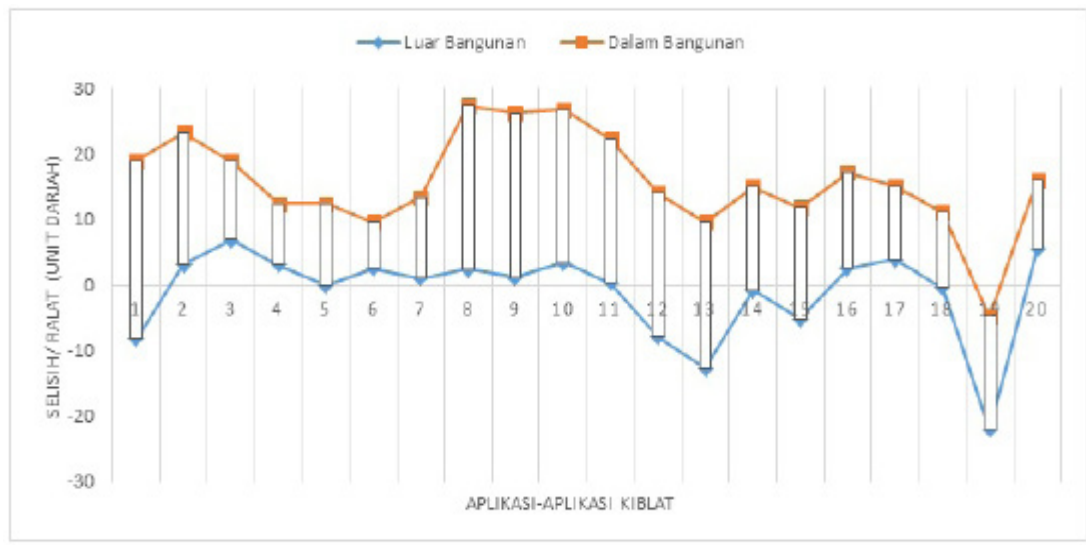

Graf 4 di atas menunjukkan graf bacaan selisih azimut kiblat antara dua lokasi yang berbeza profile iaitu luar dan dalam bangunan. Luar bangunan Blok D APIUM mempunyai profile bebas tarikan magnet pada jarak 3 meter dari pengaruh kawasan besi. Manakala Blok C (dalam bangunan) dipilih sebagai lokasi cerapan mewakili kawasan tarikan magnet. Fokus graf ini adalah untuk menunjukkan kesan perbezaan yang sangat ketara jika aplikasi kiblat digunakan di kedua-dua profile kawasan tersebut. 
Graf biru mewakili selisih azimut untuk luar bangunan Blok D APIUM, manakala graf oren mewakili selisih bacaan untuk dalam bangunan.

Daripada graf di atas, dapat disimpulkan, pengaruh tarikan magnet di blok C APIUM memberi kesan ralat yang sangat tinggi sehingga mencapai hampir $30^{\circ}$ bagi aplikasi Qibla +5 , Athan Plus dan iQibla. Namun bacaan selisih yang ditunjukkan oleh aplikasi Qibla Direction (green interface) menunjukkan nilai yang agak kecil iaitu $-4^{\circ}$ berbanding selisih azimut yang ditunjukkan di lokasi luar bangunan blok D APIUM iaitu sebanyak $-22^{\circ}$. Ini menunjukkan aplikasi ini kurang tepat malah mengalami ketidakstabilan dalam memberi bacaan yang betul. Bacaan aplikasi kiblat yang diiktiraf iaitu Easy Qibla dan MyJakim menunjukkan bacaan kurang $6^{\circ}$ di lokasi bebas tarikan magnet, sebaliknya nilai yang ditunjukkan jauh tersasar di lokasi tarikan magnet iaitu $17.0771^{\circ}$ dan $+16.0271^{\circ}$ masing-masing.

Daripada jadual 4 serta graf 2 hingga 4 di atas, dapat disimpulkan bahawa penggunaan aplikasi kiblat dalam telefon pintar sangat mudah terdedah kepada ralat bacaan kiblat yang sebenar walaupun cerapan dilakukan di kawasan bebas tarikan magnet seperti lokasi kajian di Masjid Lanchang Pahang. Ini kerana sifat kompas sangat terdedah kepada ralat. Ketika mengambil bacaan sekalipun, bacaan hendaklah diambil setelah jarum kompas benarbenar berhenti, kemudian barulah kompas digerakkan perlahanlahan sehingga angka nol benar-benar tepat menunjukkan arah utara pada alat kompas. Ini kerana jarum kompas sangat sensitif terhadap pergerakan. Terdapat beberapa faktor yang perlu diambil kira ketika mengambil bacaan menggunakan kompas. Pertama ialah saiz kompas. Semakin besar kompas, semakin stabil jarum kompas tersebut. Jika kompas yang digunakan kecil, maka ketepatannya sehingga $5^{\circ}$, sebaliknya jika kompas yang digunakan bersaiz besar, maka kadar ketepatannya sehingga $1^{\circ} .{ }^{61}$

Kedua, bacaan sudut kompas yang diperolehi perlu mengambil kira magnetic variation (variasi magnet) atau dikenali juga sebagai magnetic declination (deklinasi magnetik). Ini kerana

61 Zahrotun Niswah, "Uji Akurasi Kompas Arah Kiblat dalam Aplikasi Android Digital Falak Versi 2.0.8 Karya Ahmad Tholhah Ma'ruf," 46. 
kompas kebiasaan menunjukkan arah utara yang dipengaruhi oleh medan magnet bumi. Medan magnet bumi sentiasa berubahubah. Namun bacaan sudut perlu dilakukan dari arah utara benar. Maka wujud selisih sudut antara utara benar (utara sejati) dengan utara magnetik yang ditunjukkan oleh kompas. Untuk mengatasi masalah variasi magnet yang ditunjukkan oleh aplikasi kiblat, maka sudut arah kiblat yang ditunjukkan oleh aplikasi kiblat perlu dilakukan pembetulan. Seterusnya nilai tersebut dibetulkan dalam bacaan sudut arah kiblat. Contohnya sudut arah kiblat yang ditunjukkan ialah $292^{\circ} 50^{\prime} \mathrm{B}$ di lokasi cerapan. Nilai variasi magnet di lokasi dan tarikh tersebut ialah $-1^{\circ} 15^{\prime} \mathrm{T}$. Maka sudut arah kiblat sebenar ialah $292^{\circ} 50^{\prime} \mathrm{B}-1^{\circ} 15^{\prime} \mathrm{T}=291^{\circ} 35^{\prime} \mathrm{B}$.

Arah kiblat sebenar $=$ Sudut arah kiblat ditunjukkan kompas \pm variasi magnet

Berdasarkan bacaan yang ditunjukkan oleh 20 aplikasi kiblat dalam kajian ini, terdapat aplikasi yang tidak stabil bacaannya seperti Qibla Direction (green interface). Pada lokasi bebas tarikan magnet, bacaannya menunjukkan ralat sehingga $15^{\circ}$. Oleh demikian, dalam semua aplikasi kiblat dalam Play Store, tidak semua aplikasi sesuai digunakan sebagai rujukan arah kiblat. Para pengguna perlu berhati-hati dan memilih aplikasi yang telah teruji ketepatannya dalam pengukuran arah kiblat. Dalam aspek hukum, Malaysia terletak jauh daripada Mekah. Oleh demikian, Muslim di Malaysia tertakluk kepada hukum mengadap 'arah' kiblat bukannya 'ain kaabah'. Namun Majlis Fatwa di Malaysia menetapkan ralat sudut arah kiblat di Malaysia tidak boleh melebihi $3^{\circ}$.

Dalam aspek arah kiblat yang ditunjukkan aplikasi kiblat, terdapat sedikit keringanan yang ditetapkan majlis fatwa. Menurut Pengerusi Majlis Fatwa Kebangsaan, Professor Emeritus Tan Sri Dr Abdul Shukor Husin menyatakan dalam hal ini, majlis fatwa tidak ada halangan sekiranya umat Islam ingin menggunakan aplikasi tertentu terutama di negara yang tidak mempunyai masjid atau surau untuk menentukan arah kiblat. Namun had pesongan 
sudut yang ditunjukkan oleh aplikasi kiblat tidak boleh melebihi $10^{\circ} .62$

\section{PENUTUP}

Aplikasi kiblat yang diiktiraf di Malaysia ialah My Jakim dan Easy Qibla. Berdasarkan kajian ini, data yang ditunjukkan oleh keduadua aplikasi tersebut menunjukkan selisihan kurang daripada $10^{\circ}$ untuk semua lokasi yang bebas pengaruh magnet pada jarak 10 meter, 5 meter dan 3 meter. Maka kedua-dua aplikasi tersebut terbukti dapat digunakan sebagai rujukan masyarakat umumnya untuk penentuan arah kiblat. Namun bagi aplikasi yang lain yang diuji, jika mengambil faktor jarak tarikan magnet terjauh pada jarak 10 meter, maka Qibla Compass - Find Direction di dapati paling tepat kerana menunjukkan selisih paling kecil. Sebaliknya jika mengambil faktor jarak 3 meter pula, Qibla AR adalah yang terbaik.

Dalam kajian ini turut menunjukkan, setiap aplikasi kiblat yang digunakan pasti memiliki ralat. Namun dalam aspek penentuan kiblat, aplikasi kiblat tidak digunakan oleh badan rasmi di Malaysia. Penentuan kiblat di Malaysia ditentukan oleh jabatan-jabatan mufti negeri. Alat yang digunakan untuk mencerap arah kiblat ialah teodolit dengan ketepatan 0.01". Oleh demikian, penentuan kiblat diyakini ketepatannya. Kebiasaan masyarakat pula menentukan arah kiblat di rumah masing-masing berpandukan arah masjid yang terdekat. Oleh demikian, arah kiblat di setiap rumah juga tidak menjadi satu isu yang besar. Disamping itu, masyarakat juga dididik untuk menyemak arah kiblat di lokasi masing-masing melalui semakan bayang istiwa' adzam yang terjadi dua kali setahun. Namun masalah menentukan kiblat terjadi apabila Muslim melancong ke luar negara ataupun ke lokasi yang tiada surau atau masjid terdekat, menyebabkan mereka menggunakan aplikasi kiblat dari telefon pintar untuk menyemak arah kiblat.

Oleh demikian, keperluan kepada penggunaan aplikasi kiblat dalam Play Store tidak dapat dinafikan. Itulah kaedah ataupun

62 Berita Harian, "Tak sah solat guna aplikasi kiblat tersasar jauh daripada Kaabah." 
alat termudah untuk digunakan dalam kalangan Muslim. Oleh itu, aplikasi kiblat merupakan satu wasilah untuk membantu Muslim. Namun, sebagai Muslim yang mementingkan ketepatan kiblat, kaedah penggunaan aplikasi hendaklah memenuhi cara yang mampu mengurangkan kadar ralat. Ini kerana selisih arah kiblat pasti berlaku apabila menggunakan aplikasi kiblat untuk menentukan kiblat. Oleh demikian, setiap Muslim perlu berusaha menggunakan aplikasi dengan cara yang terbaik. Pertama, gunakan aplikasi yang diiktiraf. Kedua, semakan arah kiblat menggunakan aplikasi hendaklah dilakukan di kawasan bebas tarikan magnet serta di kawasan lapang. Ketiga, kaedah cerapan arah kiblat hendaklah dilakukan dengan cara yang betul seperti meletakkan telefon pintar di kawasan mendatar. Akhir sekali, aplikasi kiblat yang digunakan pastikan ralatnya tidak melebihi $10^{\circ}$. Ini bermakna, pengguna perlu mempunyai pengetahuan yang baik tentang aplikasi tersebut dan mengujinya dahulu sebelum menggunakannya di lokasi sebenar penentuan arah kiblat. Dengan cara ini, ralat sudut arah kiblat dapat dikurangkan dengan sebaiknya.

\section{PENGHARGAAN}

Kami ingin mengucapkan ribuan terima kasih kepada pihak Universiti Malaya melalui Geran Penyelidikan Bantuan Kecil Penyelidikan (BK006-2017) yang ditaja oleh pihak universiti. Menerusi geran ini, bantuan kewangan serta peralatan dapat disalurkan seterusnya kajian ini dapat direalisasikan dengan jayanya.

Artikel ini juga telah dibentangkan dalam Seminar Hukum Islam Semasa ke-10 (SHIS X) Peringkat Kebangsaan 2020 pada $17 \& 18$ November 2020 bertempat di Jabatan Fiqh dan Usul, Akademi Pengajian Islam Universiti Malaya Kuala Lumpur secara atas talian melalui medium Microsoft Team. Artikel ini juga telah terpilih dan diawardkan antara lima artikel terbaik dalam seminar tersebut. Terima kasih kepada pihak penganjur seminar kerana memberi peluang kepada kami untuk berkongsi hasil penyelidikan ini. 


\section{RUJUKAN}

Agustian Noor. "Aplikasi Kisah 25 Nabi dan Rasul Berbasis Android." Jurnal Sains dan Informatika 2, no. 2 (2016), 7682.

Aminatuz Zahrah \& Achmad Fawaid. "Halal Food di Era Revolusi Industri 4.0: Prospek dan Tantangan." Jurnal Hayula: Indonesian Journal of Multidisciplinary Islamic Studies 3, no. 2 (2019), 121-138.

Anisah Budiwati. "Tongkat Istiwa' Global Positioning System (GPS) dan Google Earth Untuk Penentuan Menentukan Titik Koordinat Bumi dan Aplikasinya dalam Penentuan Arah Kiblat." Jurnal Al-Ahkam 26, no. 1 (2016), 65-92.

Anum Hamee, Hafiza Anisa Ahmed \& Narmeen Zakaria Bawan, "Survey, Analysis and Issues of Islamic Android Apps," Elkawnie: Journal of Islamic Science and Technology 5, no. 1 (2019), 1-15.

Berita Harian, "Tak sah solat guna aplikasi kiblat tersasar jauh daripada Kaabah," https://www.bharian.com.my/taxonomy/ term/1303/2017/07/288125/tak-sah-solat-guna, dicapai pada 29 Mei 2017.

Chui Yin Wong, Chee Weng Khong \& Kimberly Chu. "Interface Design Practice and Education Towards Mobile Apps Development." Procedia - Social and Behavioral Sciences 51 (2012), 698-702.

Delikostidis, Ioannis, Thore Fechner, Holger Fritze, Ahmed Mahmoud AbdelMouty \& Christian Kray. "Evaluating Mobile Applications in Virtual Environments: A Survey." International Journal of Mobile Human Computer Interaction 5, no. 4 (2013): 1-19.

Esteban Vazquez-Cano. "Mobile Distance Learning with Smartphones and Apps in Higher Education." Educational Sciences: Theory \& Practice, 14, no. 4 (2014), 1505-1520.

Fajar Fathurahman. "Innovative Development of Mobile Application for Qibla Direction Guidance Services Training." Ilomata International Journal of Social Science 1 , no. 3 (2020), 88-102. 
Fajri Zulia Ramdhani. "Kontribusi Pemuda dalam Digitalisasi Ilmu Falak Pada Aplikasi Islamicastro dan Faza Haul." (Latihan Ilmiah, Ijazah Sarjana, Pascasarjana Universitas Islam Negeri Sunan Ampel, Surabaya, 2020).

Febria Roosita Dwi. "IOS Application for Finding Halal Food, Mosque, Qibla Direction and Prayer Time." Jurnal Informatika 13, no. 2 (2015), 63-70.

Frans Mayra. "Playful Mobile Communication: Services Supporting the Culture of Play." Interactions: Studies in Communication \& Culture 3, no. 1 (2012), 55-70.

H. Ahmad Izzuddin. "Metode Penentuan Arah Kiblat dan Akurasinya." (Kertas kerja, Conference Proceeding Annual International Conference on Islamic Studies AICIS IAIN Sunan Ampel Surabaya, Indonesia, 2012).

Harleen K. Flora, Xiaofeng Wang \& Swati V. Chande. "An Investigation on the Characteristics of Mobile Applications: A Survey Study." I.J. Information Technology and Computer Science, 11 (2014), 21-27.

Heather Kennedy-Eden \& Ulrike Gretzel. "A Taxonomy of Mobile Applications in Tourism." (Research Online, University of Wollongong, 2012).

Hemraj Saini. "Google Playstore Application Analysis and Prediction." (Latihan Ilmiah, Ijazah Sarjana Komputer Sains dan Engineering, Universiti Teknologi Maklumat JaypeeWaknaghat, India, 2019).

Henry Muccini, Antonio Di Francesco \& Patrizio Esposito. "Software Testing of Mobile Applications: Challenges and Future Research Directions." (Proceeding, Paper Presented on International Workshop on Automation of Software Test (AST), Zurich, Switzerland on 2-3 June 2012).

Ir. Budi Handrianto. "Islamisasi Ilmu Pengetahuan di Era Revolusi Industri 4.0 (Makna dan Tantangannya)." The Annual Conference on Islamic Education and Social Science 1, no. 1 (2019), 1-13. 
Janet E. Dickinson, Viachaslau Filimonau, Tom Cherrett, Nigel Davies, Julia F. Hibbert, Sarah Norgate \& Chris Speed. "Life-share Using Mobile Apps in Tourism: The Role of Trust, Sense of Community and Existing Lift-share Practices." Transportation Research Part D 61 (2018), 397405.

Jonathan P. Rossing, Willie M. Miller, Amanda K. Cecil \& Suzan E. Stamper. "iLearning: The Future of Higher Education? Student Perceptions on Learning with Mobile Tablets." Journal of the Scholarship of Teaching and Learning (2011), 1-27.

Kara Clayton, Thurston High School \& Amanda Murphy. "Smartphone Apps in Education: Students Create Videos to Teach Smartphone Use as Tool for Learning." Journal of Media Literacy Education 8, no. 2 (2016), 99-109.

Karandeep Singh, Kaitlin Drouin, Lisa P. Newmark, JaeHo Lee, Arild Faxvaag, Ronen Rozenblum, Erika A. Pabo, Adam Landman, Elissa Klinger, and David W. Bates. "Many Mobile Health Apps Target High-Need, High-Cost Populations, But Gaps Remain." Health Affairs 35 (2016), 12.

Karima Moumane, Ali Idri \& Alain Abran. "Usability Evaluation of Mobile Applications Using ISO 9241 and ISO 25062 Standard." Springer Plus 5 (2016), 548.

Kasinyo Harto. "Tantangan Dosen PTKI di Era Industri 4.0." Jurnal Tatsqif: Jurnal Pemikiran dan Penelitian Pendidikan 16, no. 1 (2018), 1-15.

Kevin Anderson, Oksana Burford \& Lynne Emmerton. "Mobile Health Apps to Facilitate Self-Care: A Qualitative Study of User Experiences." PLOS ONE (2016), 1-21.

M.A. Ghufron. "Revolusi Industri 4.0: Tantangan, Peluang dan Solusi Bagi Dunia Pendidikan." (Kertas kerja, Seminar National dan Diskusi Panel Multidisplin Hasil Penelitian dan Pengabdian Kepada Masyarakat, Jakarta, Indonesia, 2 Ogos 2018). 
Mahmoud I Abdallah Ibrahim \& Norashikin. "Universal Qibla and Prayer Time Finder." International Journal of Electrical and Computer Engineering (2009), 1816-1821.

Mazumder, T. A., Student, M. S., Light, F., Networking, S., \& Players, V. "Mobile Application and Its Global Impact 1." International Journal of Engineering \& Technology 10, no. 6 (2010), 72-78.

Muhammad Amiral. "Aplikasi Pengingat Shalat dan Arah Kiblat Menggunakan Global Positioning System (GPS) Berbasis Android 1.6." (Projek Akhir Peringkat Ijazah, Program Studi Teknik Informatika, Institut Teknologi Indonesia, Indonesia, 2010).

Muhammad Nu'man Alkarim. "Perancangan Aplikasi Perhitungan Rashdul Kiblat Harian Dengan Java 2 Micro Edition (J2ME) Pada Mobile Phone." (Latihan Ilmiah Ijazah Sarjana, Jurusan Ilmu Falak Fakultas Syariah Universiti Islam Negeri Walisongo, Semarang, Indonesia, 2015).

Mustofa Kamal. "Teknik Penentuan Arah Kiblat Menggunakan Aplikasi Google Earth dan Kompas Kiblat RHI.” Jurnal Madaniyah 2, no. 9 (2015), 176-197.

Nik Mohd Firdaus Nik Zainal Abidin, Farahwahida Mohd Yusof \& Nurshuhadak Hehsan. "Aplikasi Iphone: Antara Teknologi Maklumat dan Komunikasi, Media Sosial dan Sebaran Dakwah." Sains Humanika 2, no. 1 (2014), 41-53.

Nilna Minakhah. "Studi Akurasi Aplikasi Android Ismicastro Versi 1.8.12 dalam Penentuan Arah Kiblat." (Latihan Ilmiah Ijazah Sarjana, Jurusan Ilmu Falak Fakultas Syariah dan Hukum Universitas Islam Negeri Walisongo Semarang, Indonesia, 2019).

Nur Sidqon. "Uji Akurasi Mizwandroid Karya Hendro Setyanto." (Latihan Ilmiah Ijazah Sarjana, Fakultas Syari'ah dan Hukum Universitas Islam Negeri Walisongo, Semarang, Indonesia, 2019).

Nurulhuda \& Muhammad Asyraff Anuar. "Analisis Perbandingan Aplikasi Penentuan Arah Kiblat dalam Telefon Pintar Asus Zenfone 2 dan Huawei P9 Lite." Voice of Academia 13, no. 2 (2018), 35-47. 
Oussama Meski, Farouk Belkadi, Florent Laroche \& Benoit Furet. "Towards A Knowledge-based Framework for Digital Chain Monitoring within the Industry 4.0 Paradigm." (Proceeding CIRP 84, 2019), 118-123.

Radoslava Kraleva \& Velin Kralev. "An Evaluation of The Mobile Apps for Children with Specia Education Needs Based on The Utility Function Metrics." International Journal on Advance Science Engineering Information Technology 8, no. 6 (2018), 2269-2277.

Rikky Wisnu Nugraha \& Endro Wibowo. "Aplikasi Pengingat Shalat dan Arah Kiblat Menggunakan GPS Berbasis Android." Jurnal LPKIA 4, no. 2 (2014), 19-24.

Robert Godwin-Jones. "Emerging Technologies Mobile Apps For Language Learning." Language Learning \& Technology 15, no. 2 (2011), 2-11.

Ronizam Ismail, Shahrul Niza Samsudin, Wahid Ab Sulaiman, Norzaimah Zainol, \& Dina Syafini Zaid. "Kajian Tinjauan Literature Terhadap Aplikasi Mudah Alih Berunsurkan Islam Islamic Mobile Apps.” (Kertas kerja, 1st International Islamic Heritage Conference, Akademi Pengajian Islam Kontemporari, UiTM Melaka, 2015).

Shubham Ruhela. "Google Playstore Application Analysis and Prediction". (Kertas Projek, Bachelor of Technology in Computer Science and Engineering, Jaypee University of Information Technology Waknaghat, India, 2019).

Sumaiya Mushroor, ShamminHaque, \& Riyadh A. Amir. "The Impact of Smart Phones and Mobile Devices on Human Health and Life." International Journal of Community Medicine and Public Health 7, no. 1 (2020), 9-15.

Tarek Haissam Mahmoud. "Qibla Orientation Device." https:// patents.google.com/patent/US8898012B2/en, dicapai pada 10 November 2020.

Wei Peng, Shaheen Kanthawala, Shupei Yuan \& Syed Ali Hussain. "A Qualitative Study of User Perceptions of Mobile Health Apps.” BMC Public Health 16 (2016), 1-11. 
Yousef Mehdipour \& Hamideh Zerehkafi. "Mobile Learning for Education: Benefits and Challenges." International Journal of Computational Engineering Research 3, no. 6 (2013), 93-101.

Zahrotun Niswah. "Uji Akurasi Kompas Arah Kiblat dalam Aplikasi Android Digital Falak Versi 2.0.8 Karya Ahmad Tholhah Ma'ruf." (Latihan Ilmiah Sarjana, Fakultas Syariah dan Hukum, Universitas Islam Negeri Walisongo, Semarang, 2018). 
Jurnal Fiqh, Vol. 17 No. 2 (2020) 267-308 